ISSN = 1980-993X-doi:10.4136/1980-993X
www.agro.unitau.br/ambi-agua
E-mail: ambi-agua@agro.unitau.br
Tel.: (12) 3625-4116

\title{
Mapeamento e avaliação da potabilidade da água subterrânea do município de Lajeado, RS, Brasil \\ (doi:10.4136/ambi-agua.74)
}

\section{Rafael Rodrigo Eckhardt'; Vianei Luís Diedrich²; Everaldo Rigelo Ferreira ${ }^{3}$; Eduardo Strohschoen $^{4}$; Letícia Craide Demaman ${ }^{5}$}

\author{
${ }^{1}$ Professor do curso de Engenharia Ambiental e coord. do Núcleo de Geoprocessamento da UNIVATES \\ E-mail: rafare@univates.br \\ ${ }^{2}$ Biólogo e Técnico do Núcleo de Geoprocessamento da UNIVATES \\ E-mail:v10diedrich@univates.br \\ ${ }^{3}$ Geólogo, Coordenador e Professor do curso de Engenharia Ambiental da UNIVATES \\ E-mail: ferreira@univates.br \\ ${ }^{4}$ Químico e Mestre em Tecnologia Ambiental \\ E-mail: edustro@uol.com.br \\ ${ }^{5}$ Bióloga e Auxiliar de Administração do Município de Lajeado \\ E-mail: sema.administrativo@lajeado-rs.com.br
}

\section{RESUMO}

Os mananciais subterrâneos ocorrem de forma extensiva e estão relativamente protegidos dos agentes de poluição em comparação aos rios e reservatórios artificiais. Essas condições, aliadas aos baixos custos de captação, favoreceram um crescimento vertiginoso no consumo de água subterrânea nas últimas décadas. Águas subterrâneas se tornaram uma alternativa importante para o abastecimento público no Brasil. Este estudo apresenta o levantamento georreferenciado dos pontos de captação de água subterrânea no município de Lajeado, RS e o diagnóstico da potabilidade dessas águas. A captação da água subterrânea na área de estudo é realizada no Aquífero Serra Geral e no Aquífero Guarani. Os pontos de captação de água subterrânea foram identificados no campo, com uso de um receptor GPS e espacializados, utilizando técnicas de geoprocessamento e sensoriamento remoto. A potabilidade da água subterrânea foi averiguada a partir da realização de análises microbiológicas e físico-químicas em 100 poços de captação de água, sendo 78 em poços tubulares e 22 em poços escavados. Para os parâmetros analisados nos poços tubulares foram gerados os mapas de isoteores e isovalores, utilizando recursos de geoestatística. No estudo foram levantados 362 poços tubulares e 253 poços escavados. Os resultados mostram que os poços escavados localizam-se predominantemente nas áreas rurais e, dos poços escavados analisados, 77,27\% apresentam níveis de contaminação além dos limites de potabilidade, não sendo adequados para o consumo. Os poços tubulares concentram-se em áreas urbanas e, pelas análises realizadas, $76,92 \%$ apresentam água com qualidade adequada para o consumo humano.

Palavras-chave: água subterrânea; análises microbiológicas e físico-químicas; padrões de potabilidade; geoprocessamento; geoestatística.

\section{Mapping and analysis of the groundwater potability in the Lajeado municipality, Rio Grande do Sul State, Brazil}

\section{ABSTRACT}

The groundwater sources spread in extensive areas and are relatively protected from pollution agents when compared to rivers and artificial reservoirs. These aspects, combined with low exploitation costs, provided a considerable growth in the groundwater use in the last 
ECKHARDT, R. R.; DIEDRICH, V. L.; FERREIRA, E. R.; STROHSCHOEN, E.; DEMAMAN, L. C. Mapeamento e avaliação da potabilidade da água subterrânea do município de Lajeado, RS, Brasil. Ambi-Agua, Taubaté, v. 4, n. 1, p. 58-80, 2009. (doi:10.4136/ambi-agua.74)

decades. Groundwater became an important alternative source for public water supply in Brazil. This paper shows the georeferenced location of the groundwater exploitation points in the Lajeado, RS municipality and the potability analyses of this water. The groundwater exploitation in the study area is accomplished in the Serra Geral and Guarani aquifers and the exploitation points were identified in field campaigns using a GPS receiver and plotted over satellite imagery using remote sensing and geoprocessing techniques. The groundwater potability assessment was based on 100 samples for microbiological and physico-chemical analyses that included 78 samples of tubular wells and 22 of dug wells. Contour maps were generated for the analyzed parameters in the tubular wells, using geostatistics procedures. In this study, 362 tubular wells and 253 dug wells were studied. The results show that the dug wells are located mainly in rural areas and $77.27 \%$ of them aren't suitable for human consumption due to high levels of contamination. The tubular wells are concentrated in urban areas and results revealed that $76.92 \%$ of them have water with suitable quality for the human consumption.

Keywords: groundwater; microbiological and physico-chemical analysis; potability standards; geoprocessing; geostatistics.

\section{INTRODUÇÃO}

De acordo com Capucci et al. (2001), devido à degradação de sua qualidade, a água doce líquida que circula em muitas regiões do mundo perdeu a característica de recurso renovável, em particular nos países ditos em desenvolvimento, na medida em que os efluentes e os resíduos domésticos e industriais são dispostos no ambiente sem tratamento ou de forma inadequada. Além disso, desequilíbrios na oferta de água à população e conflitos pelo seu uso também apresentam aspectos preocupantes.

Diante desse cenário turbulento, a água subterrânea vem assumindo uma importância cada vez mais relevante como fonte de abastecimento. Devido a uma série de fatores que restringem a utilização das águas superficiais, bem como ao crescente aumento dos custos da sua captação, adução e tratamento, a água subterrânea está sendo reconhecida como alternativa viável aos usuários e tem apresentado uso crescente nos últimos anos, obtidas em poços bem locados e construídos. Além dos problemas relacionados à facilidade de contaminação das águas superficiais, o maior interesse pelo uso da água subterrânea vem sendo despertado pela maior oferta desse recurso e em decorrência do desenvolvimento tecnológico, que promoveu uma melhoria na produtividade dos poços e um aumento de sua vida útil (Capucci et al., 2001).

Segundo Rebouças et al. (2006), a partir da década de 1960 o termo águas subterrâneas é utilizado apropriadamente para designar a totalidade das águas do subsolo. A partir desse período, a abordagem evoluiu da tradicional determinação das reservas de água disponíveis no subsolo, das vazões de produção das obras de captação ou dos poços tubulares, para uma análise mais abrangente das suas condições de uso e proteção. Assim, tornou-se necessário considerar os principais tipos de água que ocorrem abaixo da superfície da Terra, como as águas do solo, da camada não saturada do subsolo e da sua zona saturada.

As águas que atingem a superfície do solo a partir das precipitações, retidas nas depressões do terreno, ou escoando superficialmente ao longo dos talvegues, podem infiltrarse por efeito das forças devido à atração molecular, aos efeitos de capilaridade e à atração gravitacional. Abaixo da superfície do solo, em função das ações dessas forças e da natureza do terreno, a água pode se encontrar na zona de aeração ou na zona saturada. Na primeira, os interstícios do solo ou rochas são parcialmente ocupados pela água, enquanto o ar preenche os 
ECKHARDT, R. R.; DIEDRICH, V. L.; FERREIRA, E. R.; STROHSCHOEN, E.; DEMAMAN, L. C. Mapeamento e avaliação da potabilidade da água subterrânea do município de Lajeado, RS, Brasil. Ambi-Agua, Taubaté, v. 4, n. 1, p. 58-80, 2009. (doi:10.4136/ambi-agua.74)

demais espaços livres e, na segunda, a água ocupa todos os vazios e se encontra sob pressão hidrostática (Pinto et al., 2008).

A percolação da água no solo varia de intensidade em função do tipo de terreno encontrado em seu caminho. Algumas formações apresentam vazios relativamente importantes e contínuos facilitando o fluxo descendente. Entretanto, se encontrar camadas menos permeáveis, a água será retardada e, eventualmente, preencherá todos os interstícios da região sobrejacente, formando as zonas saturadas (Pinto et al., 2008). Uma parcela desses fluxos deságua na superfície dos terrenos, formando fontes, olhos de água, abastece os poços e outras obras de captação. Outra parcela dos fluxos de água subterrânea da zona saturada deságua nos rios, tornando-os perenes durante períodos em que as precipitações atmosféricas são relativamente escassas ou descarregam diretamente nos lagos e oceanos (Rebouças et al., 2006).

A rocha que tem porosidade e permeabilidade é chamada de aquífera, independentemente de estar ou não saturada. Quando a camada aquífera em apreço apresenta grande espessura saturada, a sua função principal poderá ser de produção de água, a qual poderá ser extraída por meio de poços tubulares perfurados, túneis ou qualquer outra obra de captação. A água subterrânea da zona saturada constitui o manancial subterrâneo propriamente dito (Rebouças et al., 2006). De acordo com Capucci et al. (2001), há três tipos básicos de aquíferos, classificados de acordo com a formação rochosa na qual está contido:

- Aquíferos granulares ou porosos: a água está armazenada e flui nos poros dos solos e das rochas sedimentares de estrutura granular. Exemplo: arenitos e aluviões;

- Aquíferos fissurais: a água circula pelas fraturas, fendas e falhas nas rochas cristalinas. Exemplo: granitos, gnaisses e diabásios;

- Aquíferos cársticos ou cavernosos: a água se faz presente e circula pelas aberturas ou cavidades causadas pela dissolução das rochas. Exemplo: calcários e mármores.

As formações geológicas portadoras de água superpostas por camadas impermeáveis são denominadas de aquíferos confinados. A sua recarga, por meio das chuvas, dá-se somente nos locais onde a formação aflora à superfície. Neles o nível hidrostático encontra-se sob pressão, causando artesianismo nos poços que captam suas águas. Já os aquíferos livres são aqueles constituídos por formações geológicas superficiais, totalmente aflorantes, portanto com a recarga no próprio local, em toda a extensão da formação. Os aquíferos livres têm a chamada recarga direta e os aquíferos confinados, a recarga indireta (Capucci et al., 2001).

Dois são os fatores fundamentais determinantes na ocorrência de águas subterrâneas em determinada área. Os fatores geológicos, que regulam as condições de ocorrência - aquífero livre, confinado ou intermediário - as características hidrodinâmicas das rochas aquíferas da área em questão - porosidade intergranular e fissuras - a extensão, espessuras e profundidades das camadas aquíferas, entre outros aspectos. Por sua vez, a quantidade e o regime de ocorrência das precipitações determinam as taxas e os processos de recarga (Rebouças et al., 2006).

A disponibilidade hídrica subterrânea e a produtividade dos poços geralmente são os principais fatores determinantes na explotação dos aquíferos. Em função do crescimento descontrolado da perfuração de poços tubulares e das atividades antrópicas, que acabam contaminando os aquíferos, a questão da qualidade da água subterrânea vem se tornando cada vez mais importante para o gerenciamento dos recursos hídricos no país (Zoby e Oliveira, 2005). Tendo em vista que a captação de mananciais superficiais muito distantes, assim como o tratamento de águas de qualidade excessivamente degradada, ou o reuso, apresentam limitações técnicas e econômicas, a utilização das águas subterrâneas constitui alternativa 
ECKHARDT, R. R.; DIEDRICH, V. L.; FERREIRA, E. R.; STROHSCHOEN, E.; DEMAMAN, L. C. Mapeamento e avaliação da potabilidade da água subterrânea do município de Lajeado, RS, Brasil. Ambi-Agua, Taubaté, v. 4, n. 1, p. 58-80, 2009. (doi:10.4136/ambi-agua.74)

promissora (Rebouças, 1992), por se tratar de uma fonte mais segura e menos onerosa (Pimentel, 1999). Por sua vez, a sua extração desordenada poderá produzir sérios impactos nas descargas dos rios, nos níveis mínimos dos reservatórios e recalques nos terrenos (Rebouças, 2004).

Segundo Rebouças (2004), as águas subterrâneas no Brasil continuam sendo extraídas livremente por meio de poços de qualidade técnica duvidosa, para o abastecimento de hotéis, hospitais, indústrias, condomínios privados e, de forma geral, todos aqueles que dispõem de recursos financeiros para abrir um poço de captação de água subterrânea. Devido à falta de controle na captação, recarga e monitoramento da água subterrânea não se tem uma avaliação segura do número de poços já perfurados, tanto no mundo quanto no Brasil. A UNESCO estima que cerca de 250 milhões de poços estão em operação no mundo. No Brasil, a água subterrânea também é explotada intensamente. Zoby e Matos (2002) estimam que existam no país pelo menos 400.000 poços. Os estados com maior número de poços perfurados, segundo Leal (1999) são: São Paulo, Bahia, Rio Grande do Sul, Ceará e Piauí.

No que diz respeito ao consumo de água no Brasil, o Instituto Brasileiro de Geografia e Estatística - IBGE (2002) aponta que 15,6 \% dos domicílios utilizam exclusivamente água subterrânea, 77,8 \% usam rede de abastecimento de água e 6,6 \% usam outras formas de abastecimento. $\mathrm{O}$ mesmo estudo ainda indica que, entre os domicílios que possuem rede de abastecimento de água, uma parte significativa utiliza água subterrânea. Embora o uso do manancial subterrâneo seja complementar ao superficial em muitas regiões, em outras áreas do país, a água subterrânea representa o principal manancial hídrico. Ela desempenha importante papel no desenvolvimento socioeconômico do país.

Enquanto a contaminação de um manancial de superfície constitui, em geral, um problema agudo e visível, identificável pela mudança da cor da água, presença de espuma, aparecimento de peixe morto, etc., a contaminação dos aquíferos é invisível e pode transformar-se em um problema crônico, na medida em que só venha a ser identificado por meio dos seus efeitos na saúde pública (Rebouças, 1992).

Segundo Rebouças (1992), as alterações na qualidade das águas subterrâneas são ditas diretas quando engendradas por substâncias naturais ou artificiais introduzidas pelo homem no ciclo geoquímico da Terra. Influências indiretas podem ser consideradas como sendo aquelas alterações da qualidade, as quais ocorrem sem adição de substâncias geradas pelo homem ou são produzidas pela interferência nos processos químicos, biológicos, físicos e hidrológicos. Quando essa degradação física, química ou bacteriológica ultrapassa os limites de potabilidade, isto é, tornando-a imprópria para o consumo, diz-se que houve contaminação. Quando a degradação fica abaixo desses limites, diz-se que há poluição (Zaporozec, 1981). De acordo com Matthess (1982), quando a água, em condições naturais, apresenta constituintes excedendo os limites de potabilidade, a contaminação será caracterizada pelo aumento nas concentrações desses elementos específicos.

De acordo com Zaporozec e Miller (2000), a contaminação das águas subterrâneas pode originar-se da superfície do solo, do solo da zona não saturada, ou do solo da zona saturada. Há pelo menos três maneiras pela qual pode ocorrer a contaminação das águas subterrâneas: infiltração, migração direta e troca entre aquíferos. A contaminação por infiltração é, provavelmente, o mecanismo mais comum de contaminação da água subterrânea. Um poluente liberado na superfície infiltra através dos poros da matriz do solo e move-se abaixo através da zona não saturada pela força da gravidade até que o topo da zona saturada seja alcançado. Depois que o poluente entra na zona saturada, ele se movimenta na direção do fluxo da água subterrânea.

Rebouças (1992) considera que todo processo antropogênico capaz de poluir ou contaminar as águas subterrâneas tem origem na superfície do solo, de modo que o papel da 
zona não saturada assume especial importância, em virtude de nesta zona se realizarem as interações do meio aquífero com o contexto ambiental natural e as formas de uso e ocupação do meio físico. O local em que um poluente se origina é um fator que pode afetar seu impacto na qualidade da água subterrânea. Se um poluente é liberado na superfície do solo, precisa se mover por numerosas camadas de solo e outros materiais na zona não saturada antes de alcançar a água subterrânea. Como o poluente se move através dessas camadas, processos físicos, químicos e biológicos em atividade reduzem o impacto eventual da substância poluente ao atingir a água subterrânea. A efetividade deste processo de atenuação aumenta com a ampliação da distância, com o aumento do tempo de concentração e a condição de permeabilidade do solo ou rocha até que a substância poluente atinja a água subterrânea (Zaporozec e Miller, 2000).

As fontes de poluição da água subterrânea são muito diversas, como resultado do uso do solo urbano, industrial e agrícola. As substâncias poluentes resultantes dessas atividades incluem, principalmente, substâncias químicas orgânicas, pesticidas, metais pesados, nitratos, bactérias e vírus (Zaporozec e Miller, 2000). Frente a esse cenário e, em virtude das zonas de águas subterrâneas degradadas serem difíceis de detectar (Freeze e Cherry, 1979), as análises microbiológicas e fisico-químicas das águas subterrâneas são importantes e requeridas (Celligoi, 1999) para a avaliação da potabilidade da água.

A indicação da potabilidade da água subterrânea para o consumo é feita a partir da análise de um conjunto de parâmetros microbiológicos e físico-químicos, de acordo com as normas vigentes no País e eventualmente as internacionais (Celligoi, 1999). No Brasil, a avaliação da potabilidade da água subterrânea é realizada considerando os limites máximos apresentados pela Portaria $n^{\circ} .518$, de 2004, do Ministério da Saúde (Brasil, 2004).

\subsection{Objetivos}

O objetivo principal deste trabalho foi traçar um panorama geral da situação de uso e diagnosticar a condição de potabilidade das águas subterrâneas captadas e utilizadas no município de Lajeado, RS. Em termos específicos, o presente estudo procurou atingir 4 grandes metas:

- Realizar o levantamento georreferenciado de todos os poços de captação de água subterrânea e subsuperficial existentes na área urbana e rural do município;

- Organizar um cadastro dos usuários de água subterrânea do município de Lajeado, contando com dados da localização geográfica dos poços, dados construtivos dos poços, dados sobre a vazão e a finalidade de uso da água;

- Realizar análises microbiológicas e físico-químicas para avaliar a condição de potabilidade das águas subterrâneas para o consumo humano;

- Organizar mapas de isoteores e isovalores dos parâmetros analisados para os poços tubulares profundos.

\subsection{Enquadramento geológico da área de estudo}

O município de Lajeado está localizado a nordeste do estado do Rio Grande do Sul, apresenta área territorial de $90,42 \mathrm{~km}^{2}$ (IBGE, 2004) e população de 67.474 habitantes (IBGE, 2007), o que confere uma densidade demográfica de 746 habitantes por $\mathrm{km}^{2}$. O abastecimento de água em Lajeado é realizado pela Companhia Riograndense de Saneamento - CORSAN, que capta a água desse rio, realiza a adução, o tratamento e a distribuição da água no município. Ao mesmo tempo, existem diversas organizações, como as Sociedades de Água, particulares e indústrias que dispõem de poços de captação de água subterrânea no município.

O município de Lajeado localiza-se na Bacia Hidrográfica do Rio Taquari-Antas, que deságua na Bacia Hidrográfica do Guaíba. Geograficamente, localiza-se no Fuso 22J, sendo 
ECKHARDT, R. R.; DIEDRICH, V. L.; FERREIRA, E. R.; STROHSCHOEN, E.; DEMAMAN, L. C. Mapeamento e avaliação da potabilidade da água subterrânea do município de Lajeado, RS, Brasil. Ambi-Agua, Taubaté, v. 4, n. 1, p. 58-80, 2009. (doi:10.4136/ambi-agua.74)

delimitado pelas seguintes coordenadas UTM SAD69: 390000 - 412000 E e 6736000 6748000 N. Em termos geológicos, de acordo com Wildner et al. (2008), as litologias aflorantes na área de estudo pertencem ao intervalo Jurássico Cretáceo da Bacia do Paraná, representadas pelos derrames basálticos (Fácies Gramado) da Formação Serra Geral e arenitos intertrápicos da Formação Botucatu. Depósitos aluviais quaternários se estendem às margens do Rio Taquari e Rio Forqueta, correspondendo aos ambientes de sedimentação provocados por inundações. A Figura 1 apresenta a localização e a geologia do município de Lajeado.


Figura 1. Mapa geológico do município de Lajeado, adaptado do Mapa Geológico do Estado do Rio Grande do Sul em escala 1:750.000 (Wildner et al., 2008).

Em termos hidrogeológicos, a área de estudo está localizada na borda sul do Aquífero Guarani, próximo às áreas de recarga regional. $\mathrm{O}$ aquífero possui características de confinado, com locais onde os parâmetros hidrodinâmicos evidenciam um comportamento semiconfinado, provavelmente relacionada a pouca espessura dos basaltos e acompanhado com um intenso fraturamento destes. Por essas características, as águas subterrâneas da região de Lajeado apresentam, em geral, uma ótima qualidade, não apresentando restrições para o consumo humano (Souza et al., 2002).

A Formação Serra Geral apresenta derrames de basaltos, andesitos, riodacitos e riolitos, de filiação toleítica, onde se intercalam arenitos intertrápicos Botucatu na base e litarenitos e sedimentos vulcanogênicos da porção mediana ao topo da sequência. Na área de estudo ocorre a Fácies Gramado (K1_ $\beta \_$gr), que consiste de derrames basálticos granulares finos a médio, melanocráticos cinza, com horizontes vesiculares preenchidos por zeolitas, carbonatos, apofilitas e saponita, estruturas de fluxo, pahoehoe comuns e intercalações com os arenitos Botucatu (Wildner et al., 2008), com espessuras de até $40 \mathrm{~m}$ (Souza et al., 2002). De acordo com um amplo estudo realizado pelo Conselho de Recursos Hídricos do Rio Grande do Sul - CRH (1997), o conjunto de rochas vulcânicas da Bacia Taquari-Antas é representado por uma sequência de até 10 derrames cuja espessura média é de $70 \mathrm{~m}$. No município de Lajeado a espessura dessa Formação varia de 10 até $500 \mathrm{~m}$.

Falhamentos ocorrem na área de estudo, separados em falhamentos regionais com direções preferenciais NE e NW de até $20 \mathrm{~km}$, e falhamentos de menor expressão com 
direções preferenciais E e NE de $500 \mathrm{~m}$ a $4 \mathrm{~km}$. Zonas de disjunção horizontal estão presentes em toda a área da porção vulcânica da Formação Serra Geral (Souza et al., 2002).

Em termos hidrogeológicos, os basaltos da Formação Serra Geral se comportam como um aquífero fraturado, onde a circulação da água se dá através das superfícies de descontinuidades geradas pelas fraturas e falhas existentes. A maior ou menor quantidade de água circulante está condicionada ao não preenchimento das fraturas por mineralizações secundárias e à largura destas. Essa Formação apresenta vazão potencial de 1 a $3 \mathrm{~m}^{3} / \mathrm{h}(\mathrm{CRH}$, 1997).

A Formação Botucatu (J3K1bt), na Bacia Hidrográfica do Rio Taquari-Antas, encontrase depositada sobre as Formações Rosário do Sul e Rio do Rasto, ocorrendo, em grande parte, recoberta pelos derrames basálticos da Formação Serra Geral. Essa Formação pode ocorrer na forma de arenitos intertrápicos entre derrames basálticos, podendo atingir espessuras da ordem de $10 \mathrm{~m}$, enquanto que a espessura total da Formação Botucatu pode atingir $200 \mathrm{~m}$. É constituída por arenitos de sedimentação eólica com marcante estratificação cruzada ( $\mathrm{CRH}$, 1997). De acordo com Souza et al. (2002), no município de Lajeado, as espessuras dessa Formação podem variar de 20 a $120 \mathrm{~m}$.

A presença dos arenitos intertrápicos individualizados ou como parte integrante de rochas mistas representa um acréscimo de potencial aquífero, em função de resultar em uma incidência maior de porosidade e permeabilidade intergranular no contexto das rochas vulcânicas, cujas porosidades e permeabilidades decorrem da maior ou menor densidade de fraturas e também do maior ou menor desenvolvimento de zonas vesiculares. A vazão potencial ou provável nessa Formação é de até $30 \mathrm{~m} 3 / \mathrm{h}(\mathrm{CRH}, 1997)$, mas poços localizados sobre os falhamentos regionais podem apresentar vazões de até $120 \mathrm{~m}^{3} / \mathrm{h}$ (Souza et al., 2002).

Os depósitos aluviais (Q4a) correspondem aos sedimentos fluviais recentes, constituídos por cascalhos, areias, siltes e argilas depositadas nas calhas dos rios e nas planícies de inundação (CRH, 1997; Wildner et al., 2008). De acordo com Souza et al. (2002), os depósitos aluviais podem alcançar espessuras de até $20 \mathrm{~m}$ e gerar vazões de até $2 \mathrm{~m}^{3} / \mathrm{h}$.

\section{MATERIAL E MÉTODOS}

Os procedimentos metodológicos para o desenvolvimento do presente estudo foram divididos em três etapas: a) levantamento georreferenciado dos poços de captação de água subterrânea; b) análises microbiológicas e fisico-químicas; c) avaliação da potabilidade das águas subterrâneas.

\subsection{Levantamento georreferenciado dos poços de captação de água subterrânea}

Esta etapa do estudo consistiu na realização de atividades exploratórias de campo para localizar os poços que realizam captação de água subterrânea no município de Lajeado, uma vez que somente alguns poucos poços apresentavam registros cadastrais na Secretaria Municipal de Meio Ambiente de Lajeado. A localização geográfica dos poços foi aferida com GPS de navegação. O sistema de coordenadas utilizado no levantamento foi o Universal Transverso de Mercator (UTM), referenciado ao South American Datum, de 1969 - SAD69.

Foram levantados os poços tubulares operantes, os poços tubulares desativados, os poços escavados operantes e os poços escavados desativados. Para cada poço localizado foi preenchida uma ficha cadastral, com os dados da situação do poço, que incluíram dados construtivos, profundidade, vazão, finalidade de uso da água e características ambientais do entorno dos poços.

Mapas temáticos da distribuição espacial dos poços de captação de água subterrânea no município de Lajeado foram organizados no Sistema de Informação Geográfica (SIG) Idrisi. 
Os dados cadastrais dos poços mapeados foram utilizados para quantificar os usuários de águas subterrâneas em Lajeado e aferir a finalidade de uso dessas águas. Além disso, esta etapa do estudo permitiu que a Secretaria Municipal de Meio Ambiente organizasse medidas administrativas para a regularização dos poços em operação e medidas de controle sobre a potabilidade das águas subterrâneas consumidas.

\subsection{Análises microbiológicas e físico-químicas}

Dos poços de captação de água subterrânea operantes no município de Lajeado foram realizadas coletas para análise da água em 100 poços. Desses poços analisados, 78 coletas foram realizadas em poços tubulares e 22 coletas ocorreram em poços escavados. A definição dos poços analisados foi realizada atendendo a uma distribuição espacial aleatória, mas procurando abranger todos os quadrantes da área de estudo.

A coleta da água subterrânea foi realizada diretamente na saída de água dos poços, a qual foi desinfetada para manter as características naturais da água subterrânea. As análises microbiológicas e físico-químicas foram realizadas pelo Laboratório de Prestação de Serviços Analíticos da UNIVATES. Foram analisados os seguintes parâmetros microbiológicos: coliformes fecais, coliformes totais e contagem total de bactérias; e físico-químicos: $\mathrm{pH}$, fósforo total, dureza total, nitrogênio, nitratos, sulfatos, chumbo, cromo e matéria orgânica.

Os parâmetros acima relacionados foram selecionados em função da complexidade das atividades humanas na área urbana, em função do uso agropecuário do solo nas áreas rurais e considerando a interação rocha-água na área de estudo. Segundo Foster e Hirata (1993), dos parâmetros analisados, os nitratos, chumbo, cromo, coliformes fecais, coliformes totais, contagem total de bactérias e matéria orgânica tem importância para a saúde, enquanto os sulfatos apresentam importância organoléptica. Além disso, os parâmetros microbiológicos, o pH e a matéria orgânica são parâmetros básicos para a caracterização da água.

\subsection{Avaliação da potabilidade das águas subterrâneas}

Ao término das etapas 2.1 e 2.2 foram identificados os poços de captação de água subterrânea que apresentavam parâmetros que ultrapassavam os limites máximos de potabilidade estabelecidos pela Portaria $\mathrm{n}^{\circ}$. 518, de 2004, do Ministério da Saúde (Brasil, 2004). Essa portaria é utilizada atualmente como norma para indicar a potabilidade da água subterrânea para fins de consumo humano no Brasil. Os poços de captação contaminados foram espacializados sobre a imagem $\mathrm{ETM}^{+}$do satélite Landsat VII (2002), órbita/ponto 222/080, composição colorida RGB543, de 04/02/2002.

As análises microbiológicas e físico-químicas realizadas nos poços amostrados permitiram a geração das curvas de isoteores ou de isovalores dos parâmetros analisados. Esses mapas de isoteores foram gerados pelo método da Krigagem ordinária pontual, com interpolador a partir de semivariogramas, utilizando-se o aplicativo Surfer 8. O processo de Krigagem estima o valor de uma variável, em uma posição $\mathrm{Z}(\chi \mathrm{i})$ não amostrada, a partir de uma pré-análise espacial do conjunto de amostras utilizando-se semivariogramas experimentais. $\mathrm{O}$ valor estimado no processo de Krigagem é dado por:

$$
\mathrm{Z}\left(\chi_{\mathrm{O}}\right)=\sum_{\mathrm{I}=1}^{\mathrm{N}} \lambda_{\mathrm{I}} \mathrm{Z}\left(\chi_{\mathrm{I}}\right)
$$

em que: $\mathrm{N}$ é o número de vizinhos medidos, $\mathrm{Z}(\chi \mathrm{i})$ utilizados na estimativa da variável e $\lambda \mathrm{i}$ são os ponderadores aplicados a cada $Z(\chi \mathrm{i})$, os quais são selecionados de forma que a estimativa obtida seja não tendenciosa. Assim, tem-se o estimador não tendencioso da Krigagem ordinária pontual dado pela fórmula: $\mathrm{E}\left[\mathrm{Z} 0-\mathrm{Z}^{*}\right]$ (Guerra, 1988). 


\section{RESULTADOS E DISCUSSÃO}

As atividades exploratórias de campo permitiram identificar, basicamente, dois sistemas de captação de água subterrânea no município de Lajeado. Um sistema mais simples, que capta a água do freático a pouca profundidade. Esses poços são conhecidos como poços escavados, rasos ou cacimbas. O outro sistema, composto por poços tubulares, profundos ou artesianos, é mais complexo. Esse sistema capta a água em grandes profundidades, do Aquífero Serra Geral e do Aquífero Guarani.

Foram localizados 615 pontos de captação de água subterrânea no município de Lajeado. Desses poços levantados, 362 consistem de poços tubulares e 253 poços são poços escavados (Figura 2). A análise dos resultados permite constatar que dos poços de captação de água subterrânea levantados em Lajeado, $14 \%$ dos poços tubulares e $27 \%$ dos poços escavados estão desativados. Em termos totais, $84 \%$ dos poços levantados continuam em operação, fornecendo água para diversas finalidades, incluindo o consumo humano.

A Figura 3 apresenta a distribuição dos poços levantados em Lajeado em função da característica de uso do solo urbano e rural. Ao analisar a Figura 3, percebe-se que $70 \%$ dos poços levantados estão localizados na área urbana, onde também ocorrem $83 \%$ dos poços tubulares. Na área rural do município, $66 \%$ dos poços consistem de poços escavados e somente $17 \%$ dos poços tubulares estão localizados na área rural.

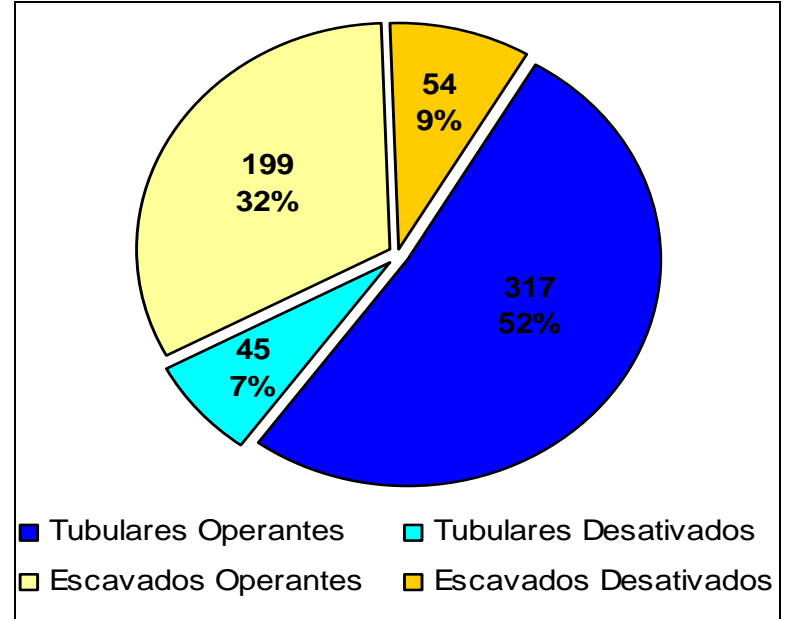

Figura 2. Tipologia e situação de uso dos poço: mapeados em Lajeado.



Figura 3. Distribuição dos poços levantados na área rural e urbana de Lajeado.

A Figura 4 apresenta a distribuição espacial dos poços tubulares e dos poços escavados operantes no município de Lajeado. A análise dessa figura permite constatar que os poços tubulares são utilizados prioritariamente na área urbana, enquanto os poços escavados ainda são utilizados intensamente nas áreas rurais. 
ECKHARDT, R. R.; DIEDRICH, V. L.; FERREIRA, E. R.; STROHSCHOEN, E.; DEMAMAN, L. C. Mapeamento e avaliação da potabilidade da água subterrânea do município de Lajeado, RS, Brasil. Ambi-Agua, Taubaté, v. 4, n. 1, p. 58-80, 2009. (doi:10.4136/ambi-agua.74)

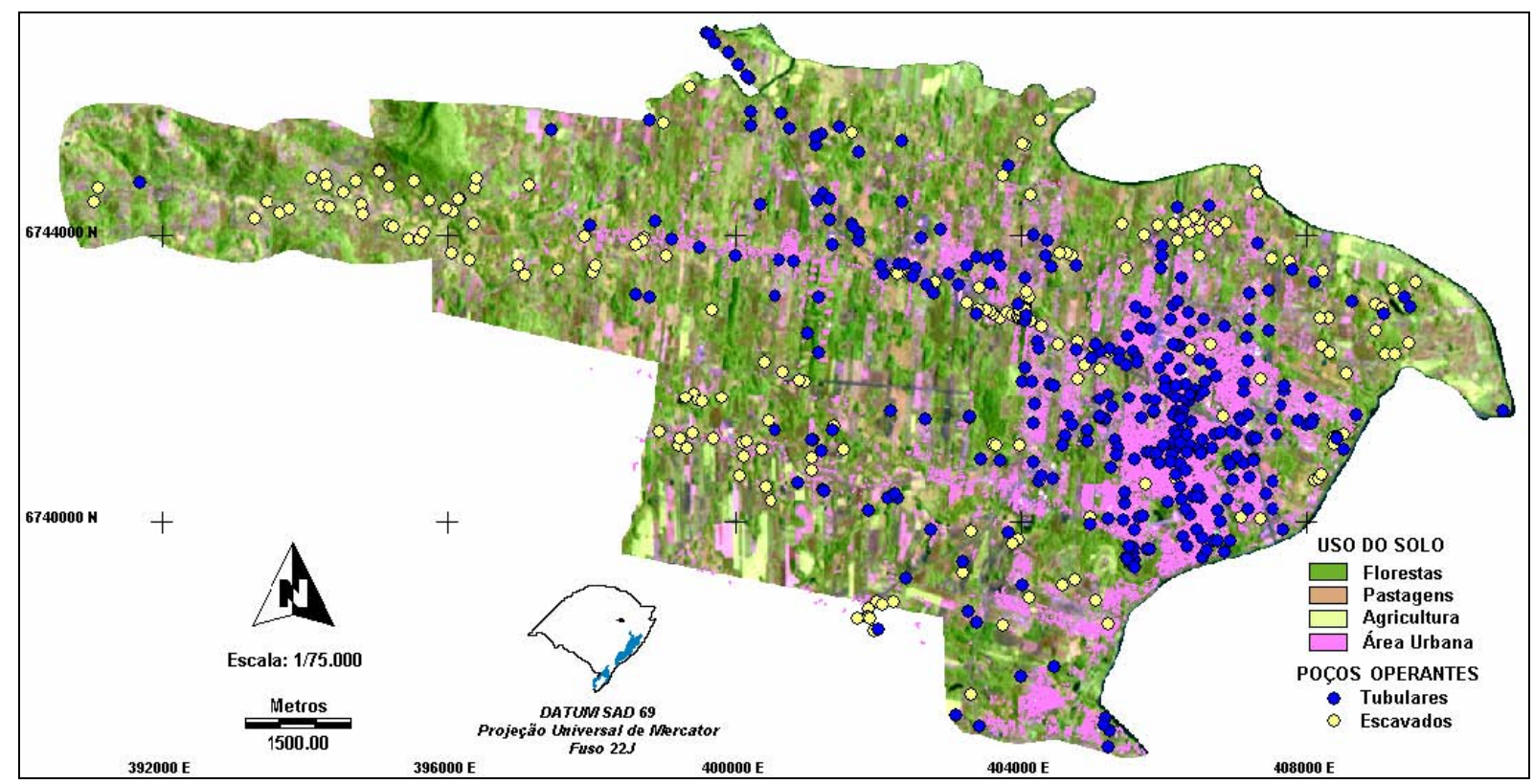

Figura 4. Localização dos poços ativos de captação de água subterrânea em Lajeado.

Em termos de consumo humano, de acordo com os dados informados pelos proprietários dos poços durante as atividades exploratórias de campo, os poços tubulares abastecem 25.797 habitantes, enquanto os poços escavados são utilizados por 670 habitantes. Em relação à população total do município de Lajeado, $29 \%$ da população correspondem aos consumidores de água subterrânea. Os $71 \%$ restantes da população são abastecidos pela rede de distribuição de água tratada da CORSAN. A Figura 5 apresenta a finalidade de uso dos 516 poços ativos levantados no município de Lajeado, de acordo com os dados cadastrais informados pelos proprietários dos poços.

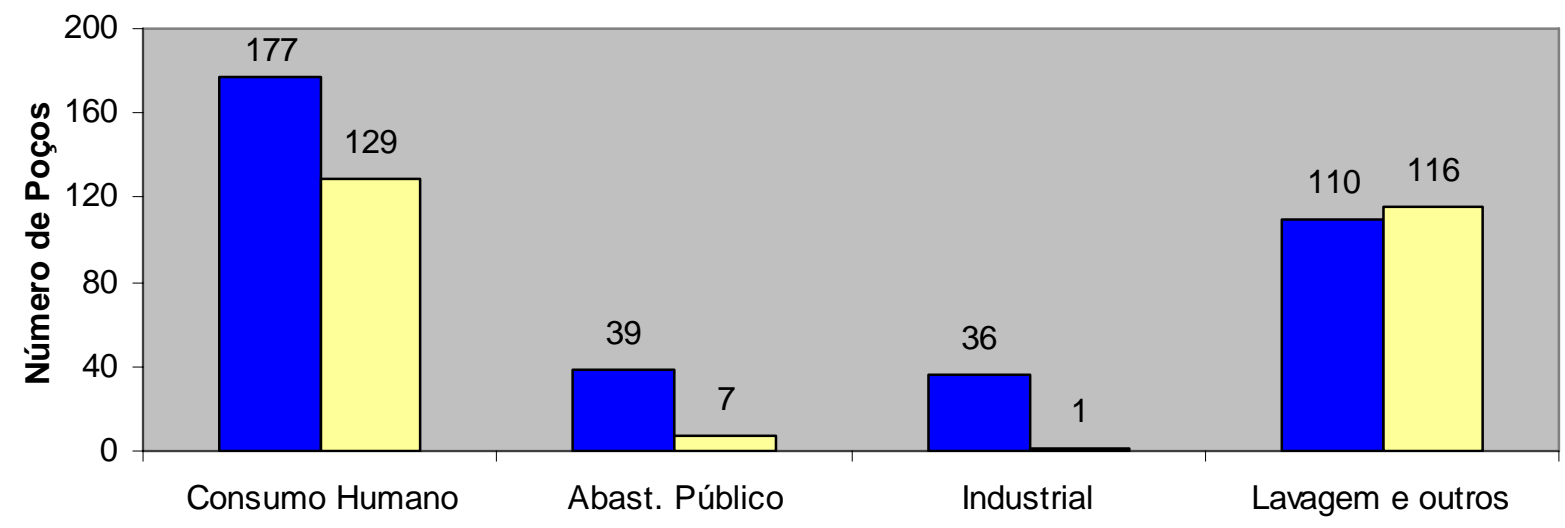

Finalidade de Uso

Poços Tubulares $\square$ Poços Escavados

Figura 5. Finalidade de uso da água subterrânea captada em Lajeado.

A análise da Figura 5 permite aferir que $59,30 \%$ dos poços são utilizados para o consumo humano, 43,80\% são utilizados para usos diversos, como, por exemplo, lavagem de veículos, limpeza, dessedentação de animais, irrigação e piscicultura. Para abastecimento público são utilizados $8,91 \%$ dos poços e 7,17\% ainda são utilizados em atividades industriais. Em virtude de alguns poços apresentarem mais de uma finalidade de uso, os percentuais de uso da água não totalizam $100 \%$. 
ECKHARDT, R. R.; DIEDRICH, V. L.; FERREIRA, E. R.; STROHSCHOEN, E.; DEMAMAN, L. C. Mapeamento e avaliação da potabilidade da água subterrânea do município de Lajeado, RS, Brasil. Ambi-Agua, Taubaté, v. 4, n. 1, p. 58-80, 2009. (doi:10.4136/ambi-agua.74)

\subsection{Avaliação físico-química e microbiológica}

Conforme descrito no capítulo dos materiais e métodos, foram amostrados 100 poços de captação de água subterrânea, sendo realizadas 78 coletas em poços tubulares e 22 coletas em poços escavados. A localização dos poços analisados está apresentada na Figura 6.

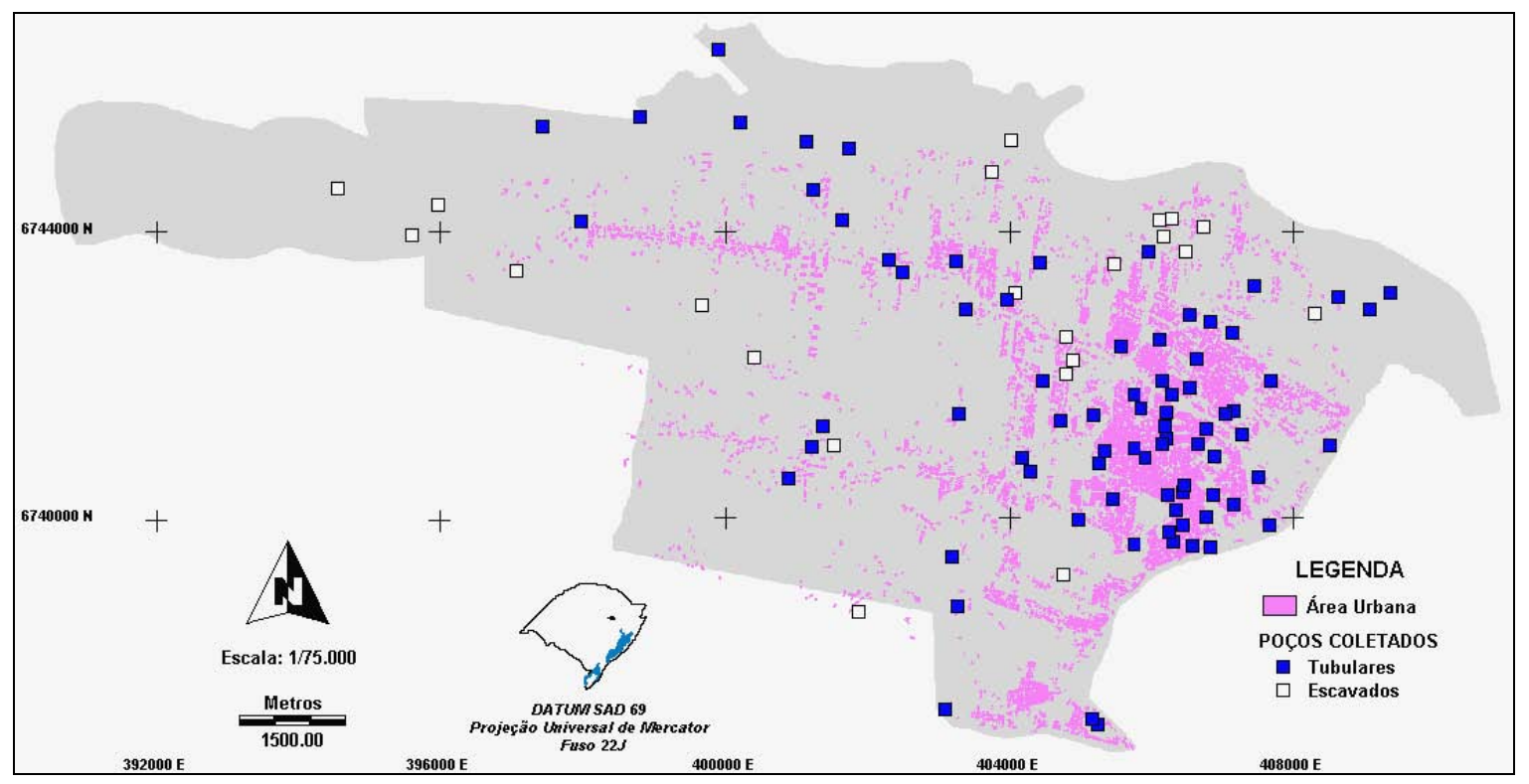

Figura 6. Poços amostrados para a realização das análises microbiológicas e físico-químicas.

A Tabela 1 apresenta o limite máximo permitido pela Portaria ${ }^{\circ} .518$ (Brasil, 2004) para os parâmetros analisados. Os poços que apresentam parâmetros dentro do limite estabelecido pela portaria apresentam água adequada ao consumo humano, sendo consideradas potáveis. Poços que apresentam água com parâmetros microbiológicos e físico-químicos além do limite máximo são considerados contaminados, não sendo adequados ao consumo humano.

Tabela 1. Valor máximo permitido pela Portaria $n^{\circ} .518$ para os parâmetros analisados.

\begin{tabular}{ll}
\hline \multicolumn{1}{c}{ Parâmetro } & Valor Máximo Permitido \\
\hline Coliformes Fecais & Ausência em $100 \mathrm{ml}$ \\
Coliformes Totais & Ausência em $100 \mathrm{ml}$ \\
Contagem Total de Bactérias Heterotróficas* & $500 \mathrm{UFC} / \mathrm{ml}$ \\
$\mathrm{pH}$ & $6,0 \mathrm{a} 9,5$ \\
Fósforo Total & Sem valor definido \\
Dureza Total & $500 \mathrm{mg} / \mathrm{L}$ \\
Nitrogênio & Sem valor definido \\
Nitratos & $10 \mathrm{mg} / \mathrm{L}$ \\
Sulfatos & $250 \mathrm{mg} / \mathrm{L}$ \\
Teor de Chumbo & $0,01 \mathrm{mg} / \mathrm{L}$ \\
Teor de Cromo & $0,05 \mathrm{mg} / \mathrm{L}$ \\
Matéria Orgânica & Sem valor definido \\
\hline
\end{tabular}

* UFC - Unidade Formadora de Colônia.

Fonte: Brasil, 2004.

A Tabela 2 apresenta os parâmetros microbiológicos e físico-químicos analisados dos 78 poços tubulares. Os teores de chumbo e cromo não constam nessa tabela, pois nenhum poço apresentou concentração acima do limite de potabilidade. 
ECKHARDT, R. R.; DIEDRICH, V. L.; FERREIRA, E. R.; STROHSCHOEN, E.; DEMAMAN, L. C. Mapeamento e avaliação da potabilidade da água subterrânea do município de Lajeado, RS, Brasil. Ambi-Agua, Taubaté, v. 4, n. 1, p. 58-80, 2009. (doi:10.4136/ambi-agua.74)

Tabela 2. Resultados das análises microbiológicas e físico-químicas realizadas nos poços tubulares.

\begin{tabular}{|c|c|c|c|c|c|c|c|c|c|c|c|c|c|}
\hline Amostra & Leste & Norte & Prof. & pH & $\begin{array}{l}\text { Fosf. } \\
\text { Total }\end{array}$ & $\begin{array}{c}\text { Dureza } \\
\text { Total }\end{array}$ & $\mathbf{N}$ & Nitratos & $s$ Sulfatos & $\begin{array}{l}\text { Mat. } \\
\text { Org. }\end{array}$ & $\begin{array}{l}\text { Col. } \\
\text { Fecais }\end{array}$ & $\begin{array}{l}\text { Col. } \\
\text { Totais }\end{array}$ & $\begin{array}{l}\text { Cont. de } \\
\text { Bactérias }\end{array}$ \\
\hline 1 & 406642 & 6742217 & 157 & 6,20 & 0,23 & 96,8 & $<0,02$ & 0,052 & 0,99 & 0,2 & 0 & 0 & 0 \\
\hline 2 & 406536 & 6741815 & 65 & 6,50 & 0,34 & 111,8 & 0,82 & 0,039 & 0,99 & 0,6 & 0 & 0 & 70 \\
\hline 3 & 407041 & 6741440 & 122 & 7,10 & 0,35 & 101 & $<0,02$ & 0,039 & 0,99 & 0,3 & 0 & 0 & 0 \\
\hline 4 & 407277 & 6741153 & 134 & 6,40 & 0,41 & 90,3 & $<0,02$ & 0,039 & 0,99 & 0,3 & 0 & 0 & 0 \\
\hline 5 & 407154 & 6741476 & 118 & 8,80 & 0,41 & 66,7 & 0,25 & 0,046 & 0,99 & 0,4 & 0 & 0 & 0 \\
\hline 6 & 409356 & 6743131 & 82 & 7,00 & 0,57 & 73,1 & 0,96 & 0,061 & 1,18 & 0,9 & 0 & 0 & 180 \\
\hline 7 & 406291 & 6741716 & 42 & 6,80 & 0,74 & 70,95 & 1,32 & 0,039 & 0,99 & 1,02 & 0 & 0 & 220 \\
\hline 8 & 406540 & 6742831 & 50 & 7,00 & 0,23 & 25,8 & 0,82 & 0,039 & 0,99 & 0,6 & 0 & 0 & 80 \\
\hline 9 & 406123 & 6742477 & 26 & 6,60 & 0,52 & 60,2 & 0,9 & 0,048 & 0,99 & 0,3 & 0 & 0 & 90 \\
\hline 10 & 406153 & 6741912 & 60 & 7,40 & 0,42 & 55,9 & 1,49 & 0,092 & 0,99 & 1,43 & 0 & 0 & 350 \\
\hline 11 & 406826 & 6742741 & 9 & 6,30 & 0,28 & 53,75 & 0,9 & 0,042 & 0,99 & 0,8 & 0 & 0 & 200 \\
\hline 13 & 402493 & 6743429 & 128 & 6,30 & 0,48 & 25,8 & $<0,02$ & 0,508 & 0,99 & 0 & 0 & 0 & 0 \\
\hline $14^{*}$ & 402294 & 6743602 & 120 & 5,60 & 0,27 & 6,45 & $<0,02$ & 3,07 & 0,99 & 0 & 0 & 0 & 0 \\
\hline 15 & 400228 & 6745523 & - & 7,00 & 0,44 & 90,3 & $<0,02$ & 0,316 & 0,99 & 0 & 0 & 0 & 0 \\
\hline 16 & 397446 & 6745478 & 160 & 9,30 & 0,22 & 19,35 & 1,6 & 0,039 & 88,6 & 2,9 & 0 & 0 & 0 \\
\hline 17 & 397985 & 6744147 & 114 & 7,60 & 0,32 & 43 & $<0,02$ & 0,039 & 75,41 & 0,08 & 0 & 0 & 0 \\
\hline 18 & 408520 & 6741010 & 80 & 6,30 & 0,71 & 38,7 & $<0,02$ & 0,658 & 0,99 & 0 & 0 & 0 & 0 \\
\hline 19 & 409068 & 6742906 & 100 & 6,50 & 0,37 & 94,6 & 1,6 & 2,42 & 3,79 & 4,3 & 0 & 0 & 80 \\
\hline 20 & 407677 & 6741904 & - & 6,60 & 0,38 & 64,5 & 0,84 & 0,242 & 0,99 & 0,3 & 0 & 0 & 0 \\
\hline 21 & 408635 & 6743083 & 99 & 7,30 & 0,685 & 77,5 & 0,41 & 0,882 & 16,3 & 0,3 & 0 & 0 & 0 \\
\hline 22 & 406768 & 6740006 & 98 & 7,40 & 0,63 & 56,5 & 0,28 & 0,723 & 3 & 1,4 & 0 & 0 & 0 \\
\hline 23 & 406868 & 6740306 & 78 & 6,10 & 0,49 & 96 & 0,28 & 0,974 & 1,57 & 1,6 & 0 & 0 & 0 \\
\hline 24 & 407444 & 6743228 & - & 6,80 & 0,55 & 52,3 & 0,41 & 0,907 & 6,54 & 1,4 & 0 & 0 & 0 \\
\hline 25 & 400903 & 6740545 & 115 & 6,70 & 0,6 & 77,5 & 0,41 & 0,836 & 0,99 & 1,6 & 0 & 0 & 40 \\
\hline 26 & 401372 & 6741274 & 76 & 6,70 & 0,99 & 62,8 & 0,41 & 0,786 & 0,99 & 0,3 & 0 & 0 & 0 \\
\hline 27 & 401216 & 6740990 & - & 6,90 & 0,74 & 90 & 0,41 & 0,685 & 0,99 & 7,4 & 0 & 0 & 0 \\
\hline 28 & 403279 & 6741453 & - & 7,10 & 0,51 & 27,2 & 0,41 & 0,874 & 0,99 & 1,4 & 0 & 0 & 0 \\
\hline 39 & 405899 & 6740820 & 30 & 7,10 & 0,66 & 107 & 0,07 & 0,468 & 6,27 & 2 & 0 & 0 & 0 \\
\hline 40 & 406897 & 6740844 & 160 & 7,00 & 0,32 & 94,2 & 0,17 & 0,619 & 16,72 & 1,4 & 0 & 0 & 320 \\
\hline 41 & 407164 & 6740180 & 119 & 6,80 & 0,4 & 124 & 0,044 & 0,886 & 12,28 & 1,4 & 0 & 0 & 0 \\
\hline 42 & 406259 & 6739795 & 75 & 7,10 & 0,34 & 117 & 0,13 & 0,401 & 11,9 & 0,78 & 0 & 0 & 210 \\
\hline 43 & 406450 & 6740345 & 66 & 7,40 & 0,98 & 211 & 0,14 & 0,389 & 8,36 & 2 & 0 & 0 & 90 \\
\hline 44 & 406242 & 6740302 & 90 & 6,90 & 0,48 & 179,4 & 0,16 & 1,15 & 13,07 & 0,15 & 0 & 0 & 0 \\
\hline 45 & 406307 & 6739658 & 88 & 7,00 & 0,87 & 125,4 & 0,2 & 1,45 & 19,47 & 0 & 0 & 0 & 0 \\
\hline 46 & 406449 & 6739876 & - & 7,30 & 0,69 & 114,6 & 0,39 & 0,69 & 2,74 & 0 & 0 & 0 & 0 \\
\hline 47 & 406475 & 6740444 & 35 & 7,30 & 0,42 & 140,5 & 0,23 & 2,03 & 7,71 & 0,3 & 0 & 0 & 0 \\
\hline 48 & 406345 & 6740096 & 54 & 7,20 & 0,65 & 179,4 & 0,22 & 0,886 & 8,1 & 0 & 0 & 0 & 0 \\
\hline 49 & 407146 & 6742575 & - & 6,6 & 0,59 & 71,3 & 0,21 & 0,685 & 2,87 & 0 & 0 & 0 & 0 \\
\hline 50 & 406590 & 6739590 & 80 & 7,3 & 0,55 & 153,5 & 0,26 & 0,807 & 10,85 & 0 & 0 & 0 & 0 \\
\hline 51 & 405756 & 6741717 & 106 & 6,95 & 0,101 & 53,56 & 1,84 & 1,17 & 0,57 & 1,5 & 0 & 0 & 0 \\
\hline 52 & 405762 & 6740963 & 130 & 6,55 & 0,05 & 41,2 & 0,86 & 0,58 & 1,39 & 1,1 & 0 & 0 & 1,3 \\
\hline 53 & 406212 & 6741092 & 120 & 6,59 & 0,07 & 93,73 & 7,12 & 6,16 & 3,27 & 1,3 & 0 & 0 & 3,2 \\
\hline $54 *$ & 406195 & 6741266 & 32 & 6,10 & 0,09 & 72,1 & 9,4 & 8,12 & 27,9 & 1,1 & 23 & 23 & 1.400 \\
\hline 55 & 404968 & 6739969 & 100 & 6,58 & 0,12 & 97,85 & 5,68 & 4,66 & 12,75 & 1,1 & 0 & 0 & 2 \\
\hline 56 & 404164 & 6740819 & 122 & 6,51 & 0,06 & 72,1 & 3,24 & 2,22 & 0,72 & 0,91 & 0 & 0 & 2,3 \\
\hline 57 & 405169 & 6741417 & 110 & 6,4 & 0,21 & 86,52 & 5,68 & 4,82 & 2,9 & 0,9 & 0 & 0 & 2,1 \\
\hline
\end{tabular}


ECKHARDT, R. R.; DIEDRICH, V. L.; FERREIRA, E. R.; STROHSCHOEN, E.; DEMAMAN, L. C. Mapeamento e avaliação da potabilidade da água subterrânea do município de Lajeado, RS, Brasil. Ambi-Agua, Taubaté, v. 4, n. 1, p. 58-80, 2009. (doi:10.4136/ambi-agua.74)

Tabela 2. Resultados das análises microbiológicas e físico-químicas realizadas nos poços tubulares (Conclusão).

\begin{tabular}{|c|c|c|c|c|c|c|c|c|c|c|c|c|c|}
\hline Amostra & Leste & Norte & Prof. & pH & $\begin{array}{l}\text { Fosf. } \\
\text { Total }\end{array}$ & $\begin{array}{c}\text { Dureza } \\
\text { Total }\end{array}$ & $\mathbf{N}$ & Nitratos & Sulfatos & $\begin{array}{l}\text { Mat. } \\
\text { Org. }\end{array}$ & $\begin{array}{l}\text { Col. } \\
\text { Fecais }\end{array}$ & $\begin{array}{l}\text { Col. } \\
\text { Totais }\end{array}$ & $\begin{array}{l}\text { Cont. de } \\
\text { Bactérias }\end{array}$ \\
\hline 59 & 405971 & 6743717 & 59 & 6,01 & 0,02 & 60,77 & 2,24 & 1,00 & 0,76 & 1,1 & 0 & 0 & 8 \\
\hline 62* & 405846 & 6741527 & 116 & 7,33 & 0,1 & 132,87 & 4,48 & 2,36 & 6,24 & 0,91 & 23 & 43 & 1,4 \\
\hline 63 & 405324 & 6740927 & 91 & 6,98 & 0,08 & 35,02 & 2,24 & 0,25 & 0,78 & 0,94 & 0 & 0 & 2 \\
\hline $64 *$ & 407667 & 6739881 & 120 & 7,05 & 0,12 & 143,17 & 1,68 & 3,15 & 81,6 & 0,81 & 0 & 0 & 880 \\
\hline 66 & 405564 & 6742380 & - & 6,63 & 0,08 & 51,84 & 5,08 & 4,92 & 0,23 & 1,1 & 0 & 0 & 9 \\
\hline 67* & 404415 & 6743559 & 70 & 5,45 & 0,08 & 61,44 & 15,56 & 14,7 & 0,86 & 1,1 & 0 & 0 & 0 \\
\hline 68* & 401743 & 6745155 & 120 & 5,84 & 0,08 & 44,16 & 1,12 & 8,7 & 1,48 & 1,1 & 0 & 0 & 380 \\
\hline 69 & 398816 & 6745597 & 80 & 6,87 & 0,1 & 75,8 & 6,28 & 5,2 & 3,38 & 1,2 & 0 & 0 & 270 \\
\hline $70^{*}$ & 399904 & 6746544 & 46 & 6,76 & 0,15 & 72 & 0,96 & 0,75 & 6,03 & 1,1 & 0 & 0 & 2.100 \\
\hline 72 & 405757 & 6739615 & 72 & 6,8 & 0,12 & 91,2 & 4,4 & 3,76 & 11,2 & 1,5 & 0 & 0 & 0 \\
\hline 73 & 403387 & 6742915 & 37 & 7,04 & 0,01 & 75,84 & 3,12 & 2,68 & 0,725 & 1,3 & 0 & 0 & 6 \\
\hline 74 & 403255 & 6743580 & 77 & 6,59 & 0,09 & 53,76 & 1,28 & 0,275 & 1,07 & 1,2 & 0 & 0 & 1 \\
\hline $75^{*}$ & 403183 & 6739440 & - & 9,73 & 0,012 & 19,2 & 0,28 & 0,168 & 43,6 & 1,1 & 0 & 0 & 8.400 \\
\hline 76 & 403259 & 6738751 & 107 & 6,75 & 0,01 & 93,12 & 0,56 & 4,39 & 3,13 & 1,05 & 0 & 0 & 2,2 \\
\hline 77 & 403963 & 6743044 & 50 & 6,03 & 0,02 & 20 & 3,92 & 0,438 & 0,824 & 1,3 & 0 & 0 & 2,1 \\
\hline 78* & 405448 & 6740253 & 130 & 8,06 & 0,06 & 39,07 & 4,76 & 0,576 & 1,25 & 1,8 & 3,6 & 9,1 & 1,7 \\
\hline 79 & 406150 & 6741024 & 100 & 6,78 & 0,07 & 168,7 & 4,48 & 3,00 & 2,82 & 1,3 & 0 & 0 & 1 \\
\hline 82* & 406656 & 6741016 & 125 & 7,05 & 0,08 & 125,7 & 2,24 & 1,50 & 17,58 & 1,5 & 23 & 23 & 1.400 \\
\hline $85^{*}$ & 401238 & 6744585 & 80 & 6,67 & 0,06 & 100 & 7,28 & 11,20 & 1,7 & 1,2 & 0 & 0 & 3 \\
\hline 86* & 401141 & 6745263 & 90 & 6,32 & 0,12 & 70 & 5,6 & 1,03 & 2,11 & 1,1 & 240 & 2400 & 13.000 \\
\hline 87 & 401643 & 6744158 & 80 & 6,44 & 0,06 & 61,8 & 4,48 & 7,17 & 1,47 & 1,12 & 0 & 0 & 7 \\
\hline 88 & 404721 & 6741339 & 108 & 6,67 & 0,06 & 52,5 & 4,48 & 4,21 & 1,7 & 1,15 & 0 & 0 & 2 \\
\hline 89* & 406210 & 6741457 & 40 & 6,86 & 0,08 & 125 & 6,72 & 11,90 & 2,72 & 1,16 & 0 & 0 & 5.500 \\
\hline 90 & 404458 & 6741910 & 103 & 6,72 & 0,06 & 67 & 5,04 & 6,24 & 1,3 & 1,1 & 0 & 0 & 3,6 \\
\hline 91 & 406837 & 6739579 & 100 & 6,57 & 0,12 & 198 & 3,92 & 8,09 & 6,19 & 1,18 & 0 & 0 & 4,1 \\
\hline 92* & 404294 & 6740642 & 62 & 6,61 & 0,06 & 76 & 4,48 & 13,70 & 1,68 & 1,17 & 0 & 0 & 0 \\
\hline 93 & 403084 & 6737292 & 80 & 6,78 & 0,1 & 217 & 5,04 & 8,47 & 8,1 & 1,13 & 0 & 0 & 6,1 \\
\hline 94* & 407503 & 6740564 & 160 & 7,13 & 0,08 & 108 & 3,36 & 10,00 & 2,88 & 1,12 & 0 & 0 & 820 \\
\hline 95* & 406774 & 6741240 & 120 & 7,43 & 0,12 & 49,4 & 4,2 & 2,50 & 24,4 & 1,2 & 0 & 0 & 500 \\
\hline 96 & 405226 & 6737096 & 26 & 6,91 & 0,16 & 51 & 3,64 & 9,50 & 6,42 & 1,2 & 0 & 0 & 7 \\
\hline 97 & 405246 & 6740743 & 100 & 6,53 & 0,08 & 60,8 & 1,12 & 0,53 & 3,27 & 1,1 & 0 & 0 & 0 \\
\hline $99 *$ & 405155 & 6737170 & 60 & 6,61 & 0,06 & 150 & 2,8 & 8,47 & 30,2 & 1,1 & 0 & 3,6 & 980 \\
\hline Média & - & - & 89,25 & 6,86 & 0,30 & 84,79 & 2,53 & 2,74 & 8,50 & 1,07 & 4,01 & 32,23 & 482,54 \\
\hline $\begin{array}{l}\text { Desvio } \\
\text { Padrão }\end{array}$ & - & - & 35,31 & 0,66 & 0,26 & 45,26 & 2,77 & 3,58 & 16,72 & 1,00 & 27,43 & 271,65 & $1.849,11$ \\
\hline
\end{tabular}

* Poços que apresentam parâmetros além do limite máximo permitido pela Portaria ${ }^{\circ}$. 518 (Brasil, 2004).

Dos 78 poços tubulares analisados, 4 poços apresentaram $\mathrm{pH}$ fora do limite de potabilidade e 5 poços apresentaram quantidade de nitratos superior ao limite máximo permitido pela Portaria $\mathrm{n}^{\circ}$. 518, de 2004. Porém, quando considerados os parâmetros microbiológicos, 12 poços, que correspondem a 15,38\% dos poços tubulares analisados, apresentaram coliformes fecais, coliformes totais ou contagem total de bactérias heterotróficas acima do limite tolerável. Considerando os parâmetros físico-químicos e microbiológicos, $23,08 \%$ dos poços tubulares analisados não atendem aos padrões de potabilidade, não sendo adequadas ao consumo humano. 
ECKHARDT, R. R.; DIEDRICH, V. L.; FERREIRA, E. R.; STROHSCHOEN, E.; DEMAMAN, L. C. Mapeamento e avaliação da potabilidade da água subterrânea do município de Lajeado, RS, Brasil. Ambi-Agua, Taubaté, v. 4, n. 1, p. 58-80, 2009. (doi:10.4136/ambi-agua.74)

Dos 78 poços tubulares amostrados para a realização das análises microbiológicas e físico-químicas, 76,92\% apresentam água potável, isto é, em condições adequadas ao consumo humano para os parâmetros analisados. A Tabela 3 apresenta os parâmetros microbiológicos e físico-químicos analisados dos 22 poços escavados.

Tabela 3. Resultados das análises microbiológicas e físico-químicas realizadas nos poços escavados.

\begin{tabular}{|c|c|c|c|c|c|c|c|c|c|c|c|c|c|}
\hline Amostra & $\mathbf{E}$ & $\mathbf{N}$ & Prof. & $\mathbf{p H}$ & $\begin{array}{l}\text { Fosf. } \\
\text { Total }\end{array}$ & $\begin{array}{c}\text { Dureza } \\
\text { Total }\end{array}$ & $\mathbf{N}$ & Nitratos & Sulfatos & $\begin{array}{l}\text { Mat. } \\
\text { Org. }\end{array}$ & $\begin{array}{c}\text { Col. } \\
\text { Fecais }\end{array}$ & $\begin{array}{c}\text { Col. } \\
\text { Totais }\end{array}$ & $\begin{array}{l}\text { Cont. de } \\
\text { Bactérias }\end{array}$ \\
\hline 12 & 406481 & 6743722 & 0,5 & 6,10 & 0,24 & 40,85 & 0,66 & 0,082 & 0,99 & 0,9 & 0 & 0 & 150 \\
\hline 29 & 406742 & 6744069 & 6,0 & 6,00 & 0,49 & 16,8 & 5,1 & 0,723 & 10,5 & 0,15 & 0 & 0 & 130 \\
\hline $30 *$ & 406179 & 6743934 & 2,0 & 6,00 & 0,73 & 16,8 & 0,38 & 0,343 & 0,99 & 0,62 & 0 & 16 & 1.100 \\
\hline $31 *$ & 406285 & 6744173 & 1,5 & 6,00 & 1,61 & 52,4 & 0,026 & & 3,14 & 0,78 & 2,2 & 16 & 1.250 \\
\hline $32 *$ & 408309 & 6742841 & 2,0 & 5,80 & 0,58 & 25,1 & 0,1 & 0,727 & 16,1 & 0 & 5,1 & 16 & 1.300 \\
\hline $33 *$ & 399679 & 6742960 & 2,5 & 6,30 & 2,82 & 35,6 & 0,17 & 0,89 & 10,2 & 0,31 & 16 & 16 & 1.750 \\
\hline $34 *$ & 395978 & 6744381 & 1,0 & 6,50 & 0,51 & 43,9 & 1,15 & 0,648 & 7,18 & 0,31 & 16 & 16 & 1.600 \\
\hline 35 & 395609 & 6743947 & 1,5 & 6,80 & 1,18 & 119 & 0,45 & & & 0,31 & 0 & 0 & 30 \\
\hline $36 *$ & 397082 & 6743452 & 2,0 & & 0,37 & & & & & 0,78 & 5,1 & 16 & 1.450 \\
\hline 37 & 401528 & 6740997 & 5,0 & 6,30 & 2,1 & 41,9 & 0,29 & 0,894 & 08 & 0,31 & 0 & 0 & 0 \\
\hline $38 *$ & 400421 & 6742236 & 10,0 & 5,80 & 0,91 & 29,3 & 0,56 & 0,84 & 18,4 & 0,31 & 0 & 0 & 40 \\
\hline $58 *$ & 405456 & 6743547 & 8,0 & 4,01 & 0,01 & 15,45 & 3,36 & & 0,33 & 1,1 & 93 & 240 & 1.600 \\
\hline $60 *$ & 404067 & 6743143 & 6,0 & 5,00 & 0,04 & 34 & 7,4 & & & 1,04 & 43 & 240 & 3.300 \\
\hline $61 *$ & 404759 & & 3,0 & 6,20 & 0,1 & 48,41 & 1,96 & 0,603 & & 0,604 & 240 & 240 & 880 \\
\hline $65 *$ & 406112 & 6744166 & 7,4 & 6,59 & 0,1 & 88,32 & 5,28 & & 1,05 & 1,3 & 240 & 240 & 7.900 \\
\hline $71 *$ & 404894 & 6742192 & 4,0 & 6,18 & 0,08 & 65,3 & 5,12 & 4,88 & 1,59 & 1,1 & 1.100 & 2.400 & 1.500 \\
\hline $80 *$ & 404016 & 6745278 & 2,5 & 7,47 & 0,04 & 72,4 & 2,8 & 0,794 & & 1,6 & 9,5 & 2.400 & 1.300 \\
\hline $81 *$ & 403740 & 6744827 & 3,0 & 6,47 & 0,03 & 95,3 & 3,36 & 2,68 & 3,51 & 1,5 & 3,6 & 43 & 1.100 \\
\hline $83 *$ & 404787 & 6742006 & 7,0 & 5,71 & 0,06 & 88,7 & 3,08 & & 2,8 & 1,6 & 93 & 460 & 1.600 \\
\hline $84 *$ & 404786 & 6742530 & 4,5 & 6,00 & 0,08 & 60 & 2,28 & 1,35 & 1,02 & 1,3 & 43 & 460 & 1.900 \\
\hline 98* & 401870 & 6738674 & 1,0 & 5,70 & 0,04 & 86,5 & 2,52 & 5,35 & 3,16 & 1,12 & 0 & 23 & 2.300 \\
\hline $100 *$ & 394550 & 6744596 & 2,0 & 7,10 & 0,05 & 65,9 & 0,28 & 4,78 & 3,34 & 1,15 & 1.100 & 1.100 & 3.700 \\
\hline Média & - & - & 3,75 & 6,12 & 0,55 & 54,29 & 2,13 & 1,92 & 5,96 & 0,83 & 136,80 & 361,00 & $1.630,91$ \\
\hline $\begin{array}{c}\text { Desvio } \\
\text { Padrão }\end{array}$ & - & - & 2,63 & 0,71 & 0,76 & 28,37 & 2,11 & 2,00 & b,69 & 0,49 & 319,61 & 707,80 & $1.699,39$ \\
\hline
\end{tabular}

* Poços que apresentam parâmetros além do limite máximo permitido pela Portaria nº. 518 (Brasil, 2004).

Em relação aos 22 poços escavados analisados, 6 poços apresentaram $\mathrm{pH}$ inferior ao limite de potabilidade estabelecido pela Portaria $n^{\circ}$. 518, de 2004, No que se refere aos parâmetros microbiológicos, 17 poços $(77,27 \%)$ apresentaram coliformes fecais, coliformes totais ou contagem total de bactérias heterotróficas superiores aos limites permitidos, não sendo adequados ao consumo humano. A Figura 7 apresenta a localização dos poços tubulares e escavados contaminados em Lajeado para os parâmetros analisados.

As profundidades dos poços tubulares em Lajeado mostraram-se bastante heterogêneas. Essa característica tem como motivos as limitações econômicas do contratante da obra, maior ou menor necessidade de água e as características litológicas e tectônicas do local de perfuração. Os resultados indicaram que a profundidade média dos poços é de 89,17 m, valor semelhante à profundidade média dos poços tubulares analisados. $\mathrm{O}$ poço mais profundo no município apresenta $207 \mathrm{~m}$ e capta água do Aquífero Guarani. Porém existem poços tubulares que estão localizados próximos à superfície, com profundidade da ordem de $10 \mathrm{~m}$ e que captam água de fraturas do Aqüífero Serra Geral. 
ECKHARDT, R. R.; DIEDRICH, V. L.; FERREIRA, E. R.; STROHSCHOEN, E.; DEMAMAN, L. C. Mapeamento e avaliação da potabilidade da água subterrânea do município de Lajeado, RS, Brasil. Ambi-Agua, Taubaté, v. 4, n. 1, p. 58-80, 2009. (doi:10.4136/ambi-agua.74)



Figura 7. Localização dos poços escavados e tubulares analisados e contaminados em Lajeado.

A vazão dos poços tubulares de Lajeado também apresentou valores heterogêneos. A maior vazão informada pelos proprietários dos poços foi de $80 \mathrm{~m}^{3} / \mathrm{h}$ em um poço com $103 \mathrm{~m}$ de profundidade. Os resultados obtidos pelas atividades exploratórias de campo indicaram que $14,53 \%$ dos poços tubulares operantes apresentam vazão de até $1 \mathrm{~m}^{3} / \mathrm{h}, 35,90 \%$ apresentam vazão de 1 a $10 \mathrm{~m}^{3} / \mathrm{h}$ e $35,04 \%$ apresentam vazão superior a $10 \mathrm{~m}^{3} / \mathrm{h}$ (Figura 8 ). A vazão média dos poços tubulares do município foi de $10,12 \mathrm{~m}^{3} / \mathrm{h}$ e desvio padrão de 10,81 $\mathrm{m}^{3} / \mathrm{h}$, confirmando que a região de Lajeado tem um bom potencial de produção de água subterrânea.

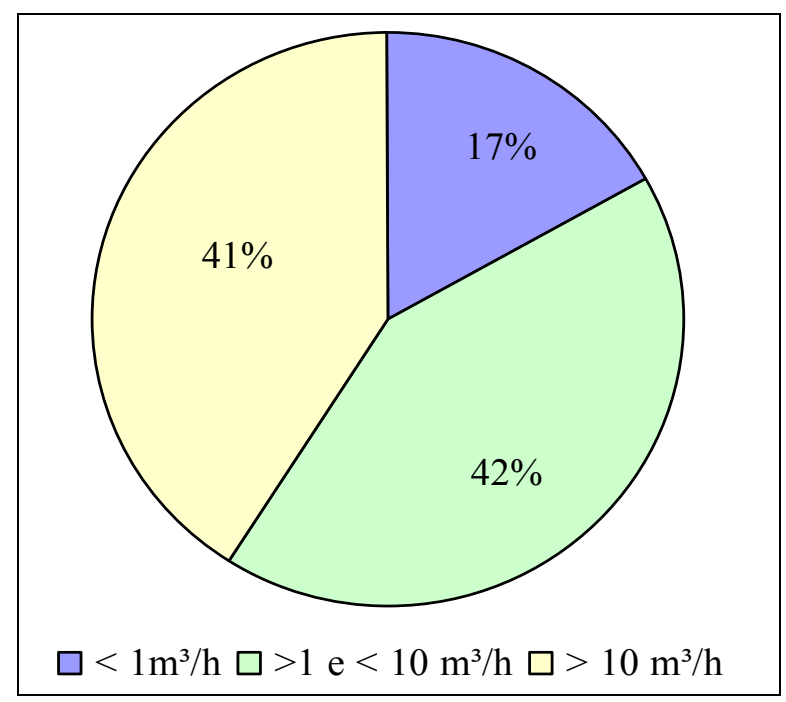

Figura 8. Vazão dos poços tubulares de Lajeado. 
ECKHARDT, R. R.; DIEDRICH, V. L.; FERREIRA, E. R.; STROHSCHOEN, E.; DEMAMAN, L. C. Mapeamento e avaliação da potabilidade da água subterrânea do município de Lajeado, RS, Brasil. Ambi-Agua, Taubaté, v. 4, n. 1, p. 58-80, 2009. (doi:10.4136/ambi-agua.74)

\subsection{Tratamento estatístico dos parâmetros analisados}

Em virtude de terem sido analisados somente 22 poços escavados, amostragem estatisticamente não significativa em relação ao total de poços escavados operantes, optou-se por não realizar nenhum tipo de tratamento estatístico com os resultados das análises microbiológicas e físico-químicas desses poços. Além disso, em virtude de captarem água dos aquíferos em profundidades e condições diferentes os tratamentos estatísticos teriam que ser realizados de forma individualizada para cada sistema de captação. Por esses motivos serão tratados estatisticamente somente os parâmetros analisados nos poços tubulares. Na sequência são apresentados os mapas com as curvas de isoteores de $\mathrm{pH}$, dureza total, nitratos, sulfatos, coliformes fecais, coliformes totais e contagem total de bactérias dos poços tubulares.

\subsection{1. pH}

$\mathrm{O} \mathrm{pH}$ dos poços tubulares variou de 5,45 a 9,73, sendo que as amostras 14, 67, 68 e 75 apresentaram valores além do limite máximo recomendado pela Portaria $n^{\circ}$. 518. Os valores mais baixos de $\mathrm{pH}$ estão localizados no entorno do Rio Forqueta e do Rio Taquari, provavelmente devido a maior proximidade das áreas de recarga e menor tempo de residência no aquífero, enquanto os maiores valores de $\mathrm{pH}$ são distribuídos de forma irregular no município (Figura 9). O pH dos poços escavados varia de 4,01 a 7,47, apresentando valores ligeiramente inferiores em comparação aos poços tubulares.

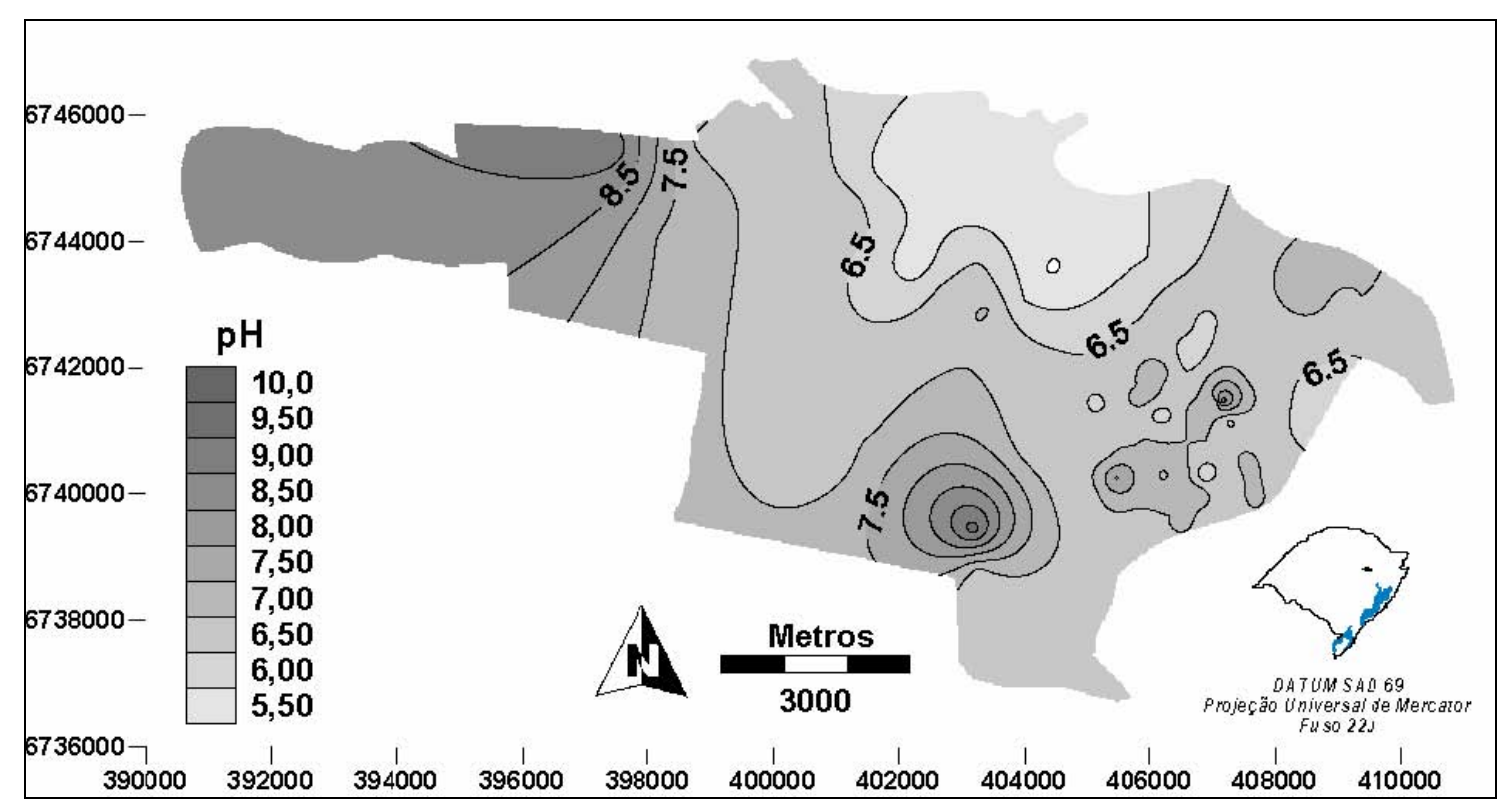

Figura 9. Curvas de isovalores de $\mathrm{pH}$ dos poços tubulares.

\subsubsection{Dureza Total}

Os teores de dureza total dos poços tubulares analisados variaram de 6,45 a $217 \mathrm{mg} / \mathrm{L} \mathrm{em}$ Lajeado, sendo semelhantes aos valores medidos por Souza et al. (2002). Esse intervalo de valores não excede o limite máximo permitido pela Portaria $\mathrm{n}^{\circ}$. 518. Os maiores valores de dureza são encontrados no centro da cidade de Lajeado a ao sul do município, onde afloram os arenitos intertrápicos da Formação Botucatu (Figura 10). De acordo com Souza et al. (2002), os maiores valores de dureza total, encontrados no centro da cidade de Lajeado, podem ser considerados anômalos, estando relacionados com mineralizações secundárias nos falhamentos da Formação Serra Geral. Os poços escavados apresentaram valores de dureza de 15,45 a $119 \mathrm{mg} / \mathrm{L}$, também dentro do limite de potabilidade. 
ECKHARDT, R. R.; DIEDRICH, V. L.; FERREIRA, E. R.; STROHSCHOEN, E.; DEMAMAN, L. C. Mapeamento e avaliação da potabilidade da água subterrânea do município de Lajeado, RS, Brasil. Ambi-Agua, Taubaté, v. 4, n. 1, p. 58-80, 2009. (doi:10.4136/ambi-agua.74)

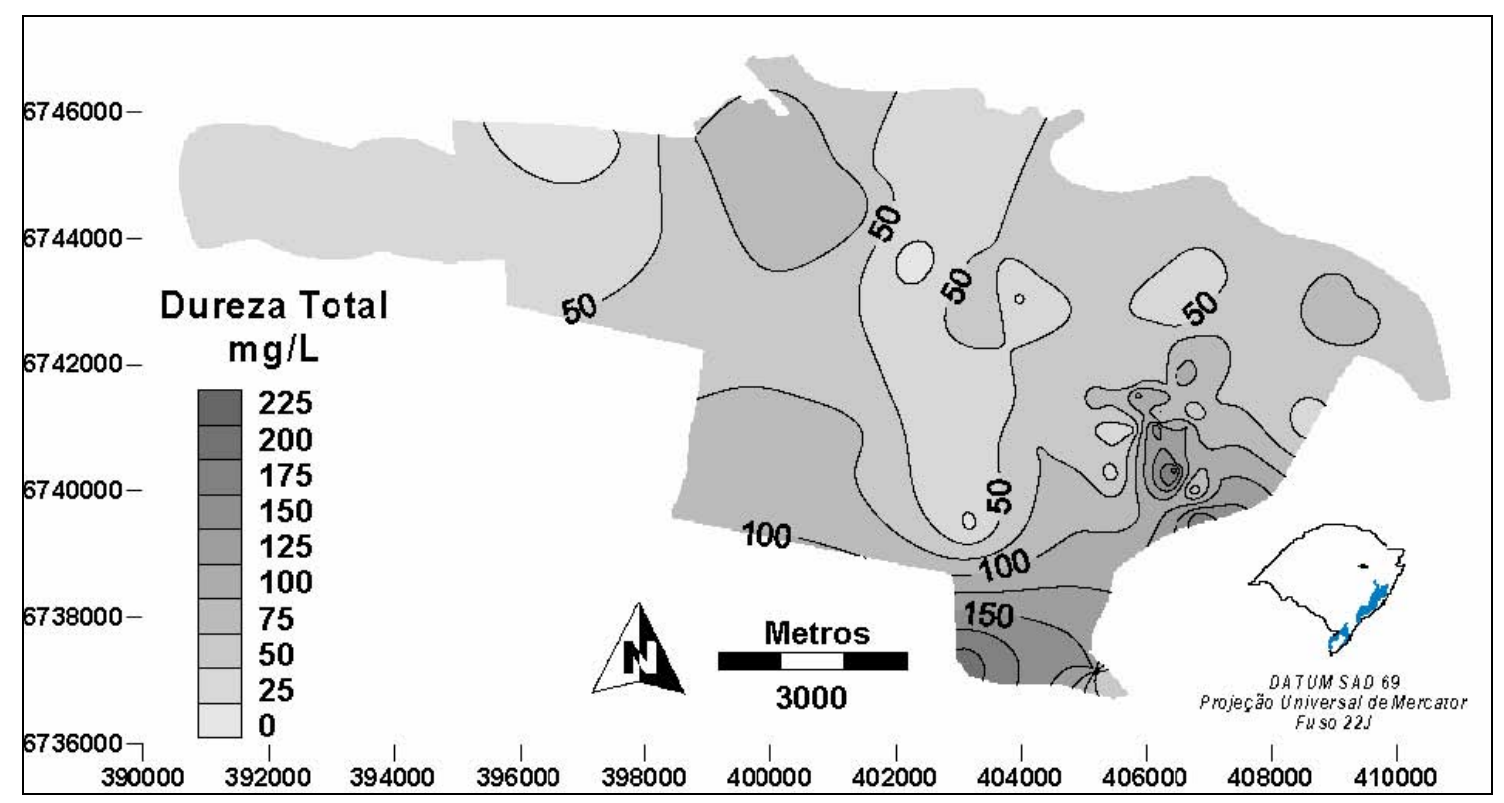

Figura 10. Curvas de isoteores de dureza total dos poços tubulares.

\subsubsection{Nitratos}

As concentrações de nitratos dos poços tubulares apresentaram valores de 0,039 a 14,7 $\mathrm{mg} / \mathrm{L}$, sendo que concentrações acima de $10 \mathrm{mg} / \mathrm{L}$ estão acima do limite de potabilidade. De acordo com Foster e Hirata (1993), o nitrato é o constituinte inorgânico mais problemático, devido a sua ampla distribuição, grande mobilidade em sub-superfície, estabilidade em sistemas aeróbios de águas subterrâneas e risco à saúde humana, principalmente em crianças e em idosos. As áreas que apresentam as maiores concentrações de nitratos estão localizadas ao norte do município, em áreas ainda caracteristicamente rurais (Figura 11). No que se refere aos poços escavados, estes apresentam valores de nitratos dentro dos limites aceitáveis de potabilidade, variando de 0,082 a $6,86 \mathrm{mg} / \mathrm{L}$.

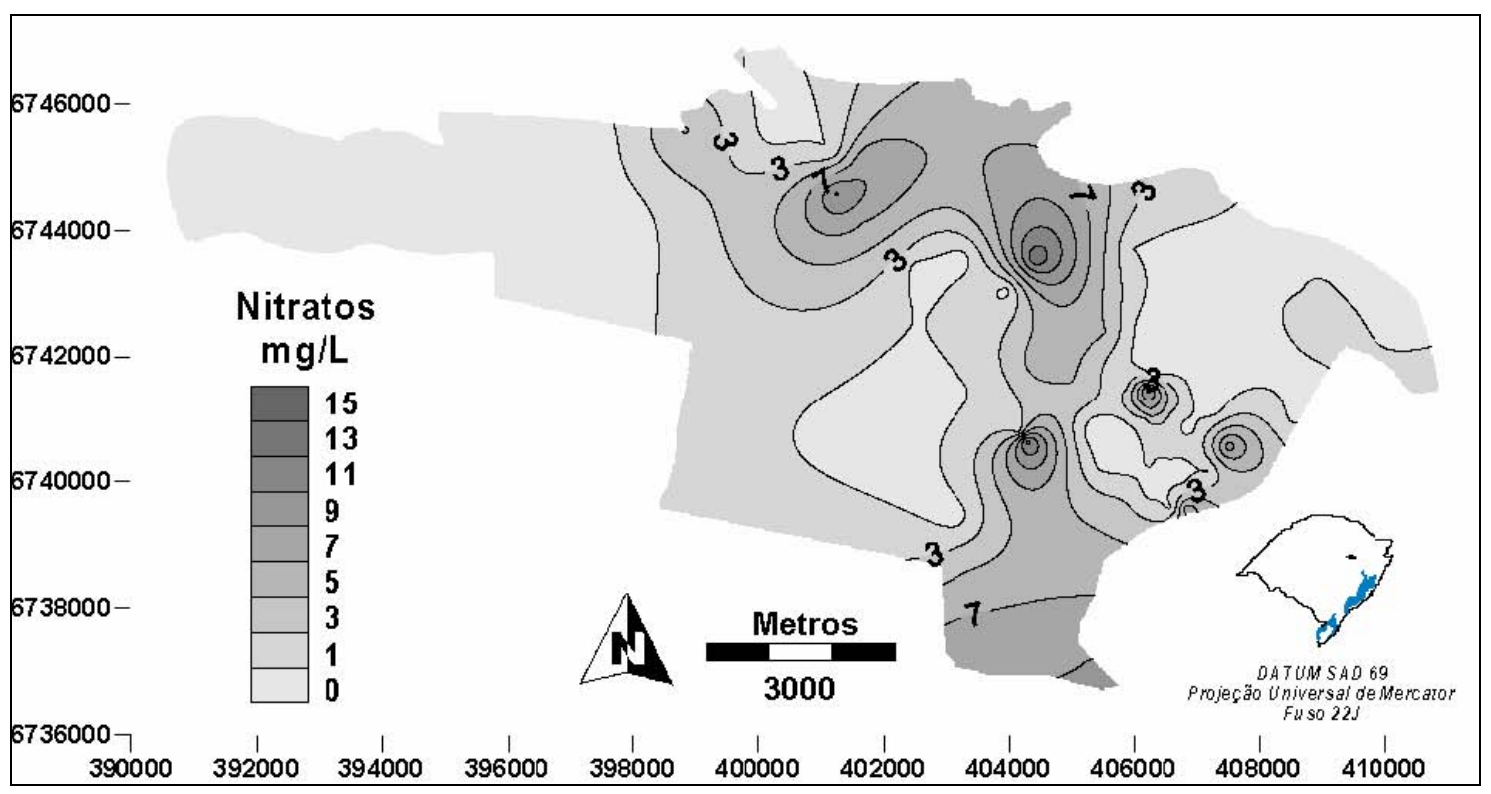

Figura 11. Curvas de isoteores de nitratos dos poços tubulares. 


\subsubsection{Sulfatos}

Os níveis de sulfatos em todos os poços tubulares e escavados analisados estão dentro dos limites de potabilidade. Nos poços tubulares variaram de 0,23 a $88,6 \mathrm{mg} / \mathrm{L}$ e nos poços escavados variaram de 0,33 a $18,4 \mathrm{mg} / \mathrm{L}$. As maiores concentrações de sulfatos estão localizados no oeste do município (Figura 12), em áreas agropecuárias e sua origem está relacionada com causas naturais, como a interação rocha-água.

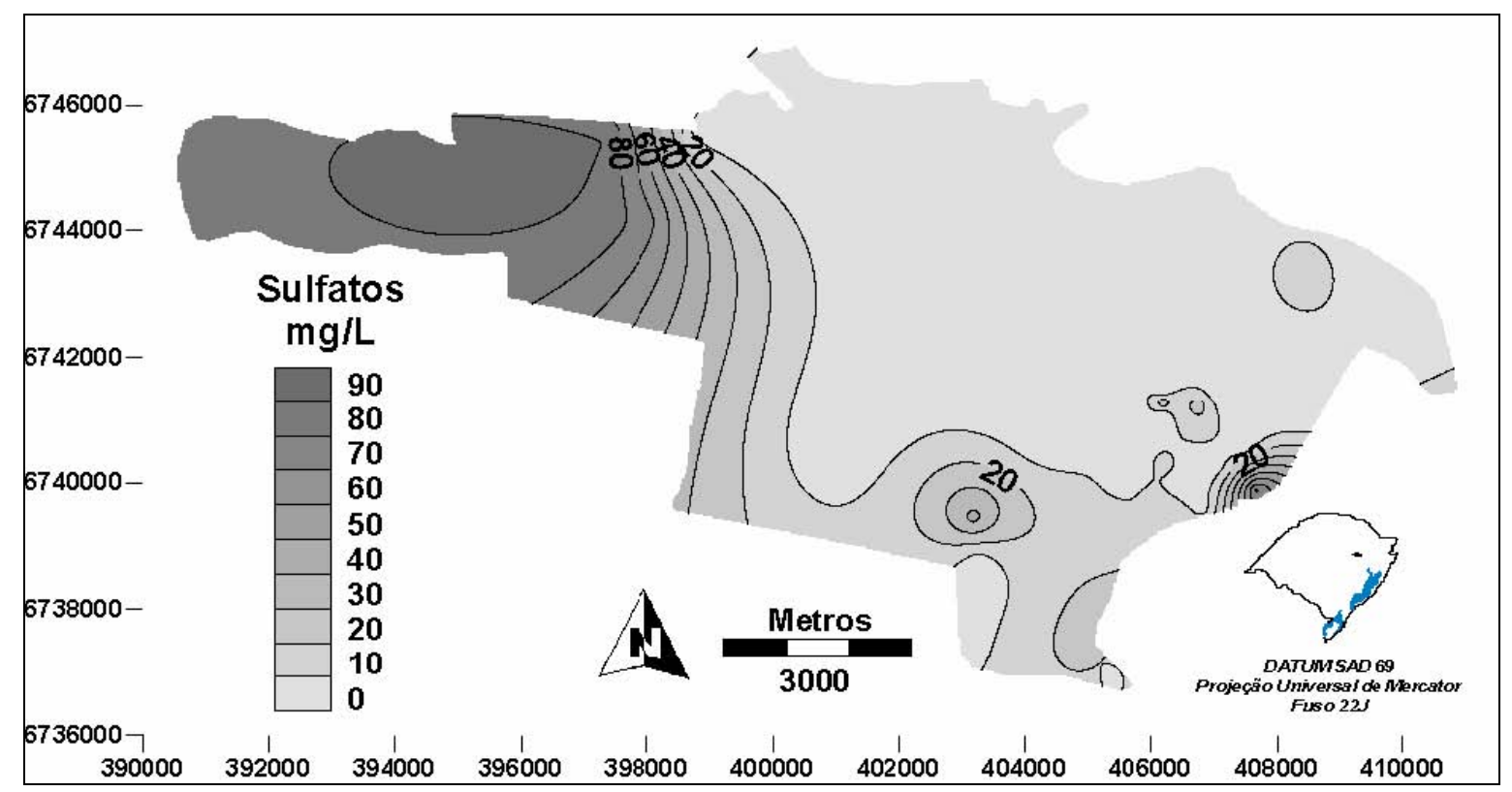

Figura 12. Curvas de isoteores de sulfatos dos poços tubulares.

Além dos parâmetros físico-químicos acima abordados, ainda foram analisados o teor de chumbo, o teor de cromo e a matéria orgânica. Tanto nos poços tubulares como nos poços escavados não foram detectados teores de chumbo e cromo acima do limite de potabilidade. Para a matéria orgânica também não se registraram valores anômalos, de modo que esses três parâmetros estão dentro dos limites de potabilidade.

\subsubsection{Coliformes fecais, coliformes totais e contagem total de bactérias heterotróficas}

As Figuras 13, 14 e 15 apresentam os mapas com as curvas de isovalores dos coliformes fecais, dos coliformes totais e contagem total de bactérias heterotróficas organizados com base nos resultados das análises microbiológicas dos poços tubulares de Lajeado. Como era esperado, esses três parâmetros apresentaram estreita associação espacial. Valores acima do limite de potabilidade foram medidos em 12 poços tubulares (de 78 analisados), localizados no centro da cidade de Lajeado e na confluência entre o Arroio Forquetinha e o Rio Forqueta. Níveis elevados de bactérias heterotróficas ainda ocorrem ao sul do município, próximo ao acesso do município de Cruzeiro do Sul. 
ECKHARDT, R. R.; DIEDRICH, V. L.; FERREIRA, E. R.; STROHSCHOEN, E.; DEMAMAN, L. C. Mapeamento e avaliação da potabilidade da água subterrânea do município de Lajeado, RS, Brasil. Ambi-Agua, Taubaté, v. 4, n. 1, p. 58-80, 2009. (doi:10.4136/ambi-agua.74)

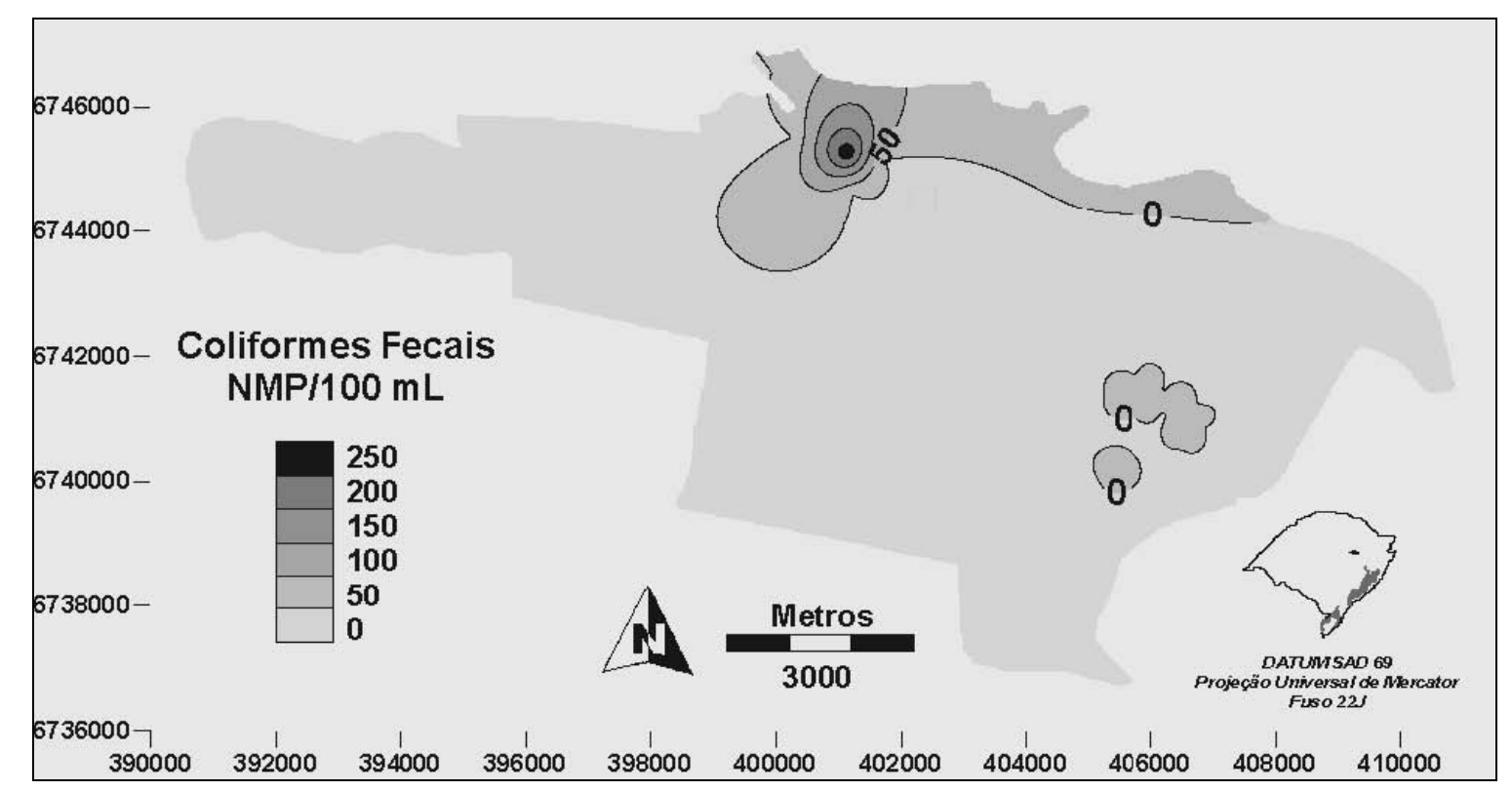

Figura 13. Curvas de isovalores de coliformes fecais dos poços tubulares.

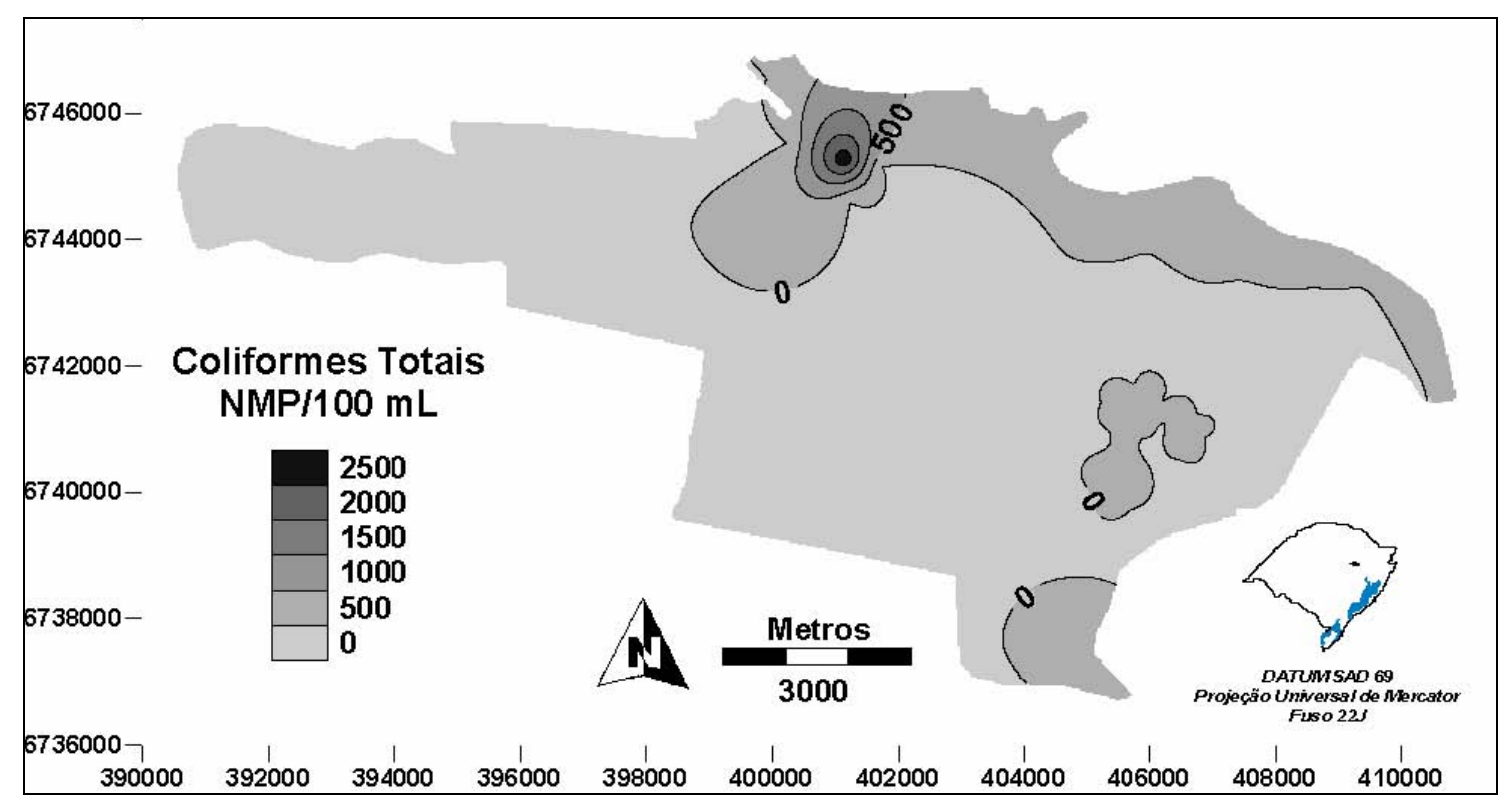

Figura 14. Curvas de isovalores de coliformes totais dos poços tubulares. 
ECKHARDT, R. R.; DIEDRICH, V. L.; FERREIRA, E. R.; STROHSCHOEN, E.; DEMAMAN, L. C. Mapeamento e avaliação da potabilidade da água subterrânea do município de Lajeado, RS, Brasil. Ambi-Agua, Taubaté, v. 4, n. 1, p. 58-80, 2009. (doi:10.4136/ambi-agua.74)

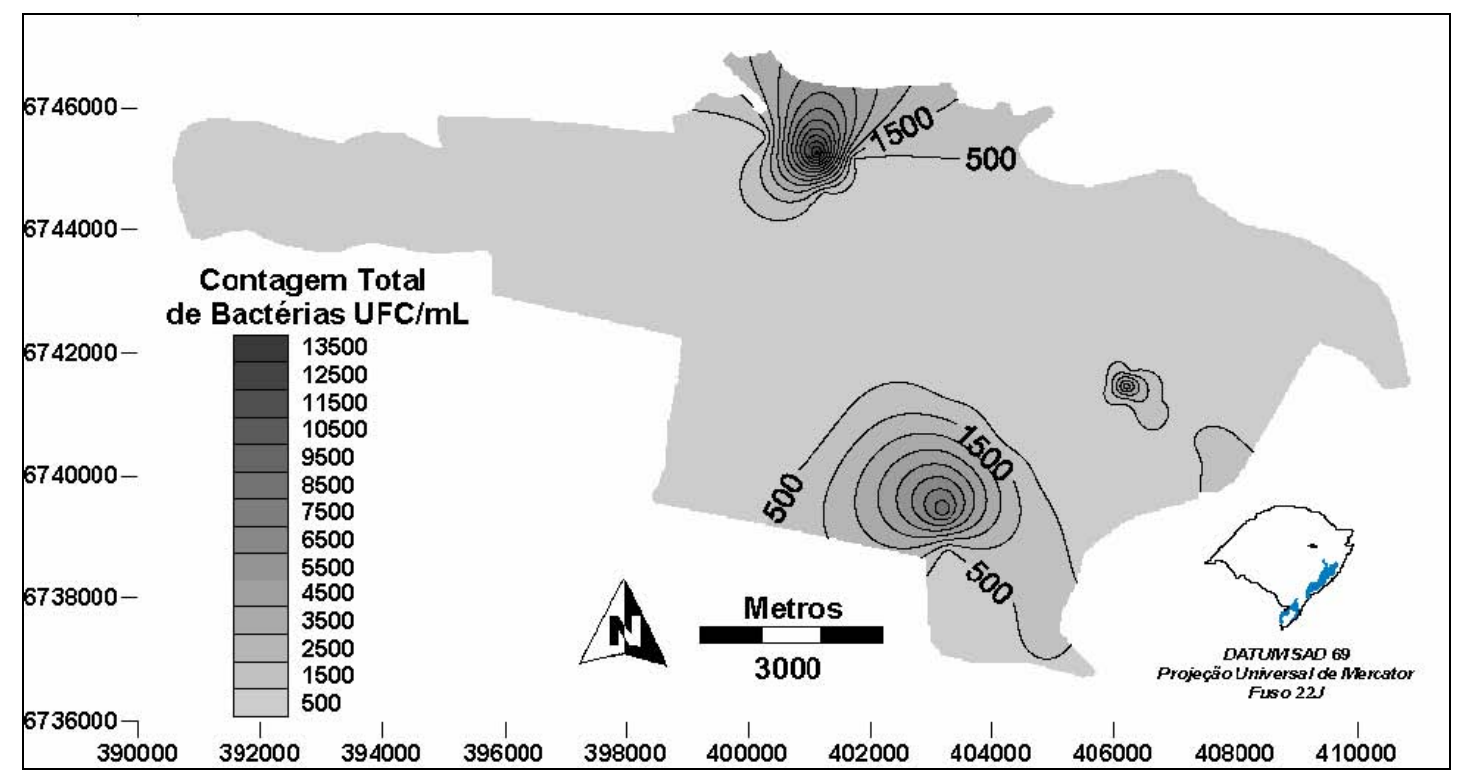

Figura 15. Curvas de isovalores de contagem total de bactérias heterotróficas dos poços tubulares.

Não foram identificadas razões suficientes para explicar a presença desses três parâmetros nos poços contaminados. As evidências indicam que existe forte contribuição dos usos antrópicos no entorno dos poços, expressos pelas áreas agrícolas e áreas urbanas, mas a contaminação microbiológica da água desses poços é potencializada por problemas construtivos. Inclusive, diversos poços tubulares operantes estão localizados em áreas de acúmulo de dejetos de suínos e bovinos, em áreas agrícolas em que ocorre fertilização com dejetos animais ou com adubação química, em áreas de enchentes e ainda em áreas sem saneamento ambiental. Qualquer problema construtivo que determinado poço tubular possa ter potencializa a contaminação da água subterrânea.

Com relação aos poços escavados, dos 22 analisados, 17 poços apresentam níveis de coliformes fecais, coliformes totais ou contagem total de bactérias heterotróficas acima do permitido para o consumo humano, estando contaminadas. A ausência de medidas sanitárias de vedação e de proteção dos poços escavados facilita a contaminação dessas águas, principalmente pelos materiais orgânicos e agentes microbiológicos. Estima-se que a grande maioria dos poços escavados, ainda em operação, não apresentam água adequado ao consumo humano.

\section{CONCLUSÕES}

Os resultados apresentados neste artigo visaram caracterizar a dimensão do consumo de água subterrânea no município de Lajeado e mensurar o estado de potabilidade dessas águas. Ressalta-se que o mapeamento dos pontos de captação de água subterrânea, a caracterização ambiental de entorno e a realização de análises microbiológicas e físico-químicas permitiram traçar um panorama geral das águas subterrâneas no município de Lajeado.

Por estar situado na borda do Aquífero Guarani e sob espessuras relativamente pequenas dos basaltos da Formação Serra Geral, as águas subterrâneas do município de Lajeado apresentam, em geral, ótima qualidade natural, não apresentando restrições de uso. Esta característica foi comprovada pelas análises físico-químicas realizadas. Além disso, os dados de vazão dos poços atualmente em operação indicam que o município apresenta alto potencial de explotação de água subterrânea. 
Ao mesmo tempo, os 15,38\% dos poços tubulares que apresentam parâmetros microbiológicos acima do limite de potabilidade indicam que existem ameaças antrópicas reais que podem afetar a qualidade das águas subterrâneas. Os usos antrópicos elevam o potencial de contaminação da água subterrânea na medida em que novos poços de captação de água subterrânea forem perfurados e sem que métodos adequados de controle sejam estabelecidos.

Quando essa análise é feita para os poços escavados, as preocupações são ainda maiores. Os resultados apontaram que $77,27 \%$ dos poços escavados analisados apresentam coliformes fecais, coliformes totais ou contagem de bactérias heterotróficas com valores muito acima do limite de potabilidade. A situação é agravada quando a água desses poços é utilizada como única fonte de água para o consumo humano, circunstância que ainda persiste na área rural do município.

Os resultados obtidos neste estudo permitiram a criação de um cadastro georreferenciado de usuários de água subterrânea no município de Lajeado. Este cadastro é mantido e atualizado pela Secretaria Municipal de Meio Ambiente de Lajeado. A partir deste cadastro, foram abertos protocolos no Departamento de Recursos Hídricos (DRH) para a obtenção da outorga pelo uso da água. Além disso, periodicamente, são solicitadas análises para mensurar a potabilidade da água subterrânea.

Salienta-se que estudos que buscam compreender a inter-relação entre os constituintes geológicos, antrópicos - como o uso do solo - e os parâmetros microbiológicos e físicoquímicos para a definição de áreas vulneráveis e críticas para a captação de águas subterrâneas no município de Lajeado são de grande relevância.

\section{AGRADECIMENTOS}

Os resultados apresentados neste artigo foram obtidos a partir de um projeto de pesquisa financiado com recursos do Centro Universitário UNIVATES, que custeou a equipe executora da pesquisa. Também o trabalho recebeu recursos do Fundo Municipal do Meio Ambiente do município de Lajeado, oriundos da aplicação de penalidades por parte do Ministério Público e teve apoio do Conselho Municipal de Defesa do Meio Ambiente, para a realização das análises microbiológicas e físico-químicas da água subterrânea. Assim sendo, os autores do artigo destinam especial agradecimento ao Centro Universitário UNIVATES e à Secretaria Municipal de Meio Ambiente de Lajeado.

\section{REFERÊNCIAS}

BRASIL. Ministério da Saúde. Portaria n ${ }^{\circ} .518$ de 25 de março de 2004. Estabelece normas e o padrão de potabilidade da água destinada ao consumo humano. Diário Oficial da União, Brasília, v. 59, p. 266-270, 26 mar. 2004, Seção1.

CAPUCCI, E.; MARTINS, A. M.; MANSUR, K. L.; MONSORES, A. L. M. Poços tubulares e outras captações de águas subterrâneas: orientação aos usuários. Rio de Janeiro: SEMADS, 2001. 70 p.

CELLIGOI, A. Considerações sobre análises químicas de águas subterrâneas. Geografia, Londrina, v. 8, n. 1, p. 91-97, 1999.

CONSELHO DE RECUROS HÍDRICOS DO RIO GRANDE DO SUL. Avaliação qualiquantitativa das disponibilidades e demandas de água na Bacia Hidrográfica do Sistema Taquari-Antas. V. 1 - memorial descritivo, Tomo 1. Porto Alegre: Magna Engenharia, 1997. 301 p. 
FOSTER, S.; HIRATA, R. Determinação do risco de contaminação das águas subterrâneas: um método baseado em dados existentes. São Paulo: Instituto Geológico, 1993. 92 p. (Boletim n. 10)

FREEZE, R. A.; CHERRY, J. A. Groundwater. New Jersey: Prentice-Hall , 1979. 604 p.

GUERRA, P. A. G. Geoestatística operacional. Brasília: Departamento Nacional de Produção Mineral - DNPM, 1988. 145 p.

INSTITUTO BRASILEIRO DE GEOGRAFIA E ESTATÍSTICA. Pesquisa nacional de saneamento básico - 2000. Rio de Janeiro: IBGE, 2002. 1 CDROM.

INSTITUTO BRASILEIRO DE GEOGRAFIA E ESTATÍSTICA. Malha municipal digital do Brasil: situação em 2001. Rio de Janeiro: IBGE, 2004. Disponível em: $<$ http://www.ibge.gov.br/>. Acesso em: 25 jan. 2008.

INSTITUTO BRASILEIRO DE GEOGRAFIA E ESTATÍSTICA. Contagem da população de 2007. Rio de Janeiro: IBGE, 2007. Disponível em: $<$ http://www.ibge.gov.br/cidadesat>. Acesso em: 25 jan. 2008.

LANDSAT ETM+ VII: imagem de satélite. Órbita/ponto 222/080, de 04/02/02. Composição colorida RGB543. GeoTiff. São José dos Campos: INPE, 2002. 1 CD-ROM.

LEAL, A. S. As águas subterrâneas no Brasil: ocorrências, disponibilidades e usos. O Estado das Águas no Brasil. Brasília: ANEEL, 1999. 1 CD-ROM. (Série Estudos e Informações Hidrológicas e Energéticas).

MATTHESS, G. The properties of groundwater. New York: Wiley-Interscience, 1982. 406 p.

PIMENTEL, R. Reserva de Água no Planeta. Bahia Análise \& Dados, Salvador, v. 9, n. 3, p.118-122, 1999.

PINTO, N. L. S.; HOLTZ, A. C. T.; MARTINS, J. A.; GOMIDE, F. L. S. Hidrologia básica. 11. Reipr. São Paulo: Edgar Blücher, 2008. 278 p.

REBOUÇAS, A. C. Impactos ambientais nas águas subterrâneas. In: CONGRESSO BRASILEIRO DE ÁGUAS SUBTERRÂNEAS, 7., 1992, Belo Horizonte. Anais... Belo Horizonte: ABAS, 1992. p.11-17.

REBOUÇAS, A. C. Uso inteligente da água. São Paulo: Escrituras, 2004. 207 p.

REBOUÇAS, A. C.; BRAGA, B.; TUNDISI, J. G. (Orgs.) Águas doces no Brasil: capital ecológico, uso e conservação. 3. ed. São Paulo: Escrituras, 2006. 749 p.

SOUZA, E. R.; SOUSA, R. J. P.; HALLMANN, J. R. Avaliação preliminar dos recursos hídricos subterrâneos da região de Lajeado - RS - Brasil. In: CONGRESSO BRASILEIRO DE ÁGUAS SUBTERRÂNNEAS, 12., 2002, Florianópolis. Anais... Florianópolis: ABAS, 2002. p.1-10.

ZAPOROZEC, A. Ground-Water pollution and its sources. GeoJournal, Springer Netherlands, v. 5, n. 5, p. 457-471, 1981.

ZAPOROZEC, A.; MILler, J. C. Ground-Water Pollution. Paris: UNESCO, 2000. p. 27. Disponível em: <http://unesdoc.unesco.org/>. Acesso em: 25 ago. 2008. 
ECKHARDT, R. R.; DIEDRICH, V. L.; FERREIRA, E. R.; STROHSCHOEN, E.; DEMAMAN, L. C. Mapeamento e avaliação da potabilidade da água subterrânea do município de Lajeado, RS, Brasil. Ambi-Agua, Taubaté, v. 4, n. 1, p. 58-80, 2009. (doi:10.4136/ambi-agua.74)

ZOBY, J. L. G.; MATOS, B. Águas subterrâneas no Brasil e sua inserção na Política Nacional de Recursos Hídricos. In: CONGRESSO BRASILEIRO DE ÁGUAS SUBTERRÂNEAS, 12., 2002, Florianópolis. Anais... Florianópolis: ABAS, 2002. 1 CD-ROM.

ZOBY, J. L. G.; OLIVEIRA, F. R. de. Panorama da qualidade das águas subterrâneas no Brasil. Brasília: ANA, 2005. 80 p. (Cadernos de Recursos Hídricos).

WILDNER, W.; RAMGRAB, G. E.; LOPES, R. C.; IGLESIAS, C. M. F. Mapa geológico do Estado do Rio Grande do Sul.. Porto Alegre: CPRM, 2008. Escala 1:750.000. 1 DVD. 